\title{
CONNECTIONS BETWEEN FLUVIAL TO SHALLOW MARINE ENVIRONMENTS AND SUBMARINE CANYONS: IMPLICATIONS FOR SEDIMENT TRANSFER TO DEEP WATER
}

\author{
MICHAEL L. SWEET ${ }^{1}$ AND MICHAEL D. BLUM ${ }^{2}$ \\ ${ }^{1}$ ExxonMobil Upstream Research Company, 22777 Springwoods Village Parkway, Spring, Texas 77389, U.S.A. \\ ${ }^{2}$ Department of Geology, 325 Lindley Hall, University of Kansas, Lawrence, Kansas 66045, U.S.A.
}

\begin{abstract}
The heads of submarine canyons represent a critical link in the transfer of sediment from terrestrial sources to deep basin sinks. Here we report data on grain size, bathymetry, and geochronology from twenty-five modern submarine canyons that suggest this link to be very sensitive to the distance between the canyon head and the shoreline, and, to a lesser extent, wave energy. These data show the width of this zone filters the caliber of sediment delivered into deep water, which has significant implications for understanding sediment budgets and the distribution of reservoir and seal facies.

Data from modern systems show that the river mouths or longshore drift cells must come within about $500 \mathrm{~m}$ of the head of the canyon to deliver gravel-size material and within 1 to $5 \mathrm{~km}$ to deliver sand-size material to be transported down the canyon into deep water. Clay- and silt-size particles are transported greater distances across the shelf, up to a few tens of $\mathrm{km}$, whereas beyond about $40 \mathrm{~km}$, little sediment makes the connection to the heads of canyons and deposits are dominated by condensed, carbonate-rich sediments.

Our data from modern systems are consistent with existing sequence stratigraphic models for sediment delivery to deep water. The significance of our work is to show in more detail how and when connections can occur between fluvial to shallow-water systems and submarine canyons and how these connections regulate the quantity and caliber of sediment that can be transported into deep water. Once the process-based conditions for connection are met, then the geology and climate of the source area control the quantity and caliber of sediment that can be moved to deep water.

We hypothesize that connection times, and the resultant fractionation of sediment mass and grain size between shelf and deep-water depocenters, may have varied in a predictable way through geologic history. For example, during greenhouse times when sea level was relatively high, but with inherently low high-frequency variability, longer-lived connections between fluvial to nearshore environments and deep water may have been more likely. This scenario would favor the preferential transfer of sediment, especially sand, into deep water, and the development of thick, laterally extensive sand-rich basin-floor deposits. By contrast, during icehouse periods, high-amplitude sea-level fluctuations and inherently wider continental shelves may have resulted in repeated landward and seaward transits of river mouths and shorelines, shorter connection times between source and sink, especially for sand-size sediment, and preferential sequestration of sediment in shelf to shelf-margin parts of the system. These conditions would have resulted in deep-water deposits that are a mixture of locally thick sands, abundant turbidity-current-derived mud, and thin but basin-wide condensed sections that represent periods of sediment starvation in deep water.
\end{abstract}

\section{INTRODUCTION}

Since the late 1930s (e.g., Daly 1936; Shepard 1941; Heezen et al. 1964) it has been recognized that large submarine canyons are found along most continental margins and function to localize turbidity-current flows. With improved technology for imaging the sea floor, and the deployment of current monitors and sediment traps in some submarine canyons, the scale and distribution of these canyons has become better defined and their role as conduits for transferring sediment from terrestrial sources into the deep basin has become better understood (e.g., Piper and Savoye 1993; Khripounoff et al. 2003; Paull et al. 2003; Smith, et al. 2005; Oliveira et al. 2007; Harris and Whiteway 2011). Indeed, as observed by Normark and
Carlson (2003), every major submarine fan in the world is fed by a submarine canyon.

This appreciation for the significance of submarine canyons has been part of a greater collective understanding of continental margins that resulted in recent years from large-scale, integrated studies of modern systems (e.g., Nittrour et al. 2007). This perspective has led to placing ancient and modern sedimentary systems in a source-to-sink (S2S) context, where sedimentary environments are viewed as part of a continuum from up-dip source areas of sediment production, routing of sediment through fluvial systems to the coastal plain and marine environments, and dispersal to their ultimate sink in the deep basin (e.g., Sømme et al. 2009). The S2S approach stresses understanding the sediment production, flux, storage, 
and the connections between sedimentary environments, with an ultimate goal of quantifying and predicting sediment mass balance and the partitioning of sediment by volume and grain size through different parts of the dispersal system.

The confluence of new high-resolution bathymetric data sets and numerous published studies on sediment fluxes and transport mechanisms on modern continental margins now makes it possible to reach a better understanding of the controls on sediment transfer to deep water. This paper explores three questions that pertain to the prediction of sediment transfer between near-shore and deep-water environments:

1. What factors control how and when sediment moves from the shelf into deep water?

2. Are existing models for sediment transfer into deep water consistent with data from Quaternary systems?

3. Can we use the understanding of how and when sediment moves from near-shore to deep-water environments to make better predictions of reservoir presence and sand percent in a wide range of tectonic and climatic settings?

\section{Existing Models for Sediment Transport from Near-Shore to Deep- Water Environments}

The apparent paradox of many modern canyons that are clearly inactive with thick, sand-rich accumulations in both extant submarine fans and deposits interpreted to represent deep-water deposition in the rock record has led to the development of several models to explain how and when sediment moves to deep water.

Sequence stratigraphic models developed by Exxon Production Research Company (EPR) in the 1970s and 1980s recognized that relative sea level (i.e., the combined effects of eustasy and subsidence) exerted a strong control on sediment delivery to deep water (Vail et al. 1977; Vail 1987; Jervey 1988; Posementier and Vail 1988). These models called upon relative sea-level fall, which could be driven by a combination of eustatic and tectonic factors, to expose the continental shelf and bring fluvial systems to the heads of submarine canyons to establish the connection between fluvial and deep-water systems (Mitchum 1985; Vail 1987; Posamentier and Vail 1988). EPR models predicted deposition of sandrich, deep-water fans during relative sea-level falls when the shelf was exposed and sediment was purged from incised valleys (Fig. 1). During relative sea-level rise, the fluvial to deep-water connection was broken and a condensed section was deposited in deep water. Although Posamentier and Vail (1988) proposed that sand deposition was most likely in deep water during relative sea-level fall, they acknowledged that sand-rich fans could locally occur in other conditions. These models have been useful exploration tools because they provide a reliable first-order understanding of the connection between fluvial to shallow marine and deep-water systems, and the resulting deposition of reservoir and seal facies, especially in passive-margin settings like the Gulf of Mexico and Congo Basin of Angola.

In contrast to the sequence stratigraphic models of the 1980s, Covault et al. (2007), Covault and Graham (2010), and Covault et al. (2010) used highresolution seismic, bathymetric, and geochronologic data from Quaternary systems to understand how the interaction between sea level, climate, shelf width, and the location of littoral cells controlled the volume of sediment delivered to deep water. The approach of these studies was different from earlier work because the focus was on the detailed observations during a small slice of the stratigraphic record in the Quaternary, a time of highfrequency, glacially driven sea-level change, and they did not explore the impact of tectonic subsidence. These models were developed using data primarily from the California Borderlands, where the continental shelf is relatively narrow and where alternating arid to humid climatic cycles can deliver a large volume of sediment during high sea level (Fig. 2). Covault and Graham (2010) recognized that globally, during the late Quaternary, the greatest volume of sediment was delivered to deep water when sea level was low, but local variations in climate and shelf geometry produced conditions where the maximum sediment flux could occur along any position of the sea-level curve (Fig. 2).

Blum and Hattier-Womack (2009) and Blum et al. (2013) proposed a third model for the controls on sediment flux to deep water. This geometric model recognized that cross-shelf transport of large volumes of sediment by marine processes was inherently process-limited, and stressed the distance between the shoreline and the canyon head as the main control on the timing and caliber of sediment that would be delivered to deep water (Fig. 3). Blum et al. (2013) considered feeder river and shelf gradient, and the amplitude of high-frequency Milankovitch-forced sea level change, to be the primary controls on shelf width, such that shelf width, $W_{s}$, scales as

$$
W_{s} \sim \Delta S L / S
$$

where $\triangle S L=$ amplitude of Milankovitch-driven sea-level change, and $S=$ slope of feeder river system. From this model, Blum et al. (2013) postulated different connection times for mixed sand to mud populations vs. mud only. They suggested that connection times would be inherently longer, with preferential mass transfer of the sand fraction, in a short-steep system with a narrow shelf in the modern icehouse world, compared with a large, low-gradient icehouse system. Connection times would also be longer in a greenhouse world of low-amplitude, low-frequency sea-level changes, compared to a sediment-dispersal system of similar scale and gradient in an icehouse world with high-amplitude, high-frequency sealevel change (see also Sømme et al. 2009). Both the Covault and Graham (2010) and Blum et al. (2013) models therefore infer that sand deposition can occur in basin-floor settings under a variety of relative sea-level positions and rates of change. An objective of this paper is to test the Blum et al. (2013) model with data from Quaternary systems.

\section{Sediment Movement Across the Shelf}

An understanding of how different grain-size populations move from river-mouth sources across the shelf is fundamental to understanding sediment transfer to deep water. It has long been recognized that most of the sand fraction is conserved within the zone defined by longshore currents. Bruun (1963) developed a conceptual model for conservation of mass within a specific depth on the shoreface, largely to predict shoreline response to sea level rise. This "depth of closure" was defined as the depth at which waves can no longer transport sand. Allen (1970) later showed that breaking waves result in a net landward-directed shear stress that conserves sand alongshore and limits transport, in most conditions, across the shelf into deeper water. He termed this process the "littoral energy fence." Hallermeier (1981) determined that the maximum depth to which sand could be transported by wave energy $\left(d_{l}\right)$ is

$$
d_{l}=228 H_{S}-685\left(H_{a}^{2} / g T_{s}^{2}\right)
$$

where $H_{s}$ is local wave height, $T_{s}$ is wave period, and $g$ is acceleration due to gravity. Hallermeier (1981) calculated that, depending on wave energy, closure depth for sand could range to $20 \mathrm{~m}$ to $40 \mathrm{~m}$ along high-energy coastlines, and showed that calculated values are consistent with observations of the maximum depth to which sand was observed on the seafloor in a number of locations along the coast of the United States. Given that shoreface slope is typically 0.5 to $2^{\circ}$ (Stutz and Pilkey 2002), the distance from shoreline to closure depth would be on the order of 0.5 to $5 \mathrm{~km}$, and the probability of transport by wave-generated currents decreases as depth increases within this narrow shore-parallel zone (e.g., Peters and Loss 2012). This result is consistent with modern longshore transport along the eastern Gulf of Mexico coast where exceedance of threshold velocity for sand transport is generally confined to depths $<12$ 

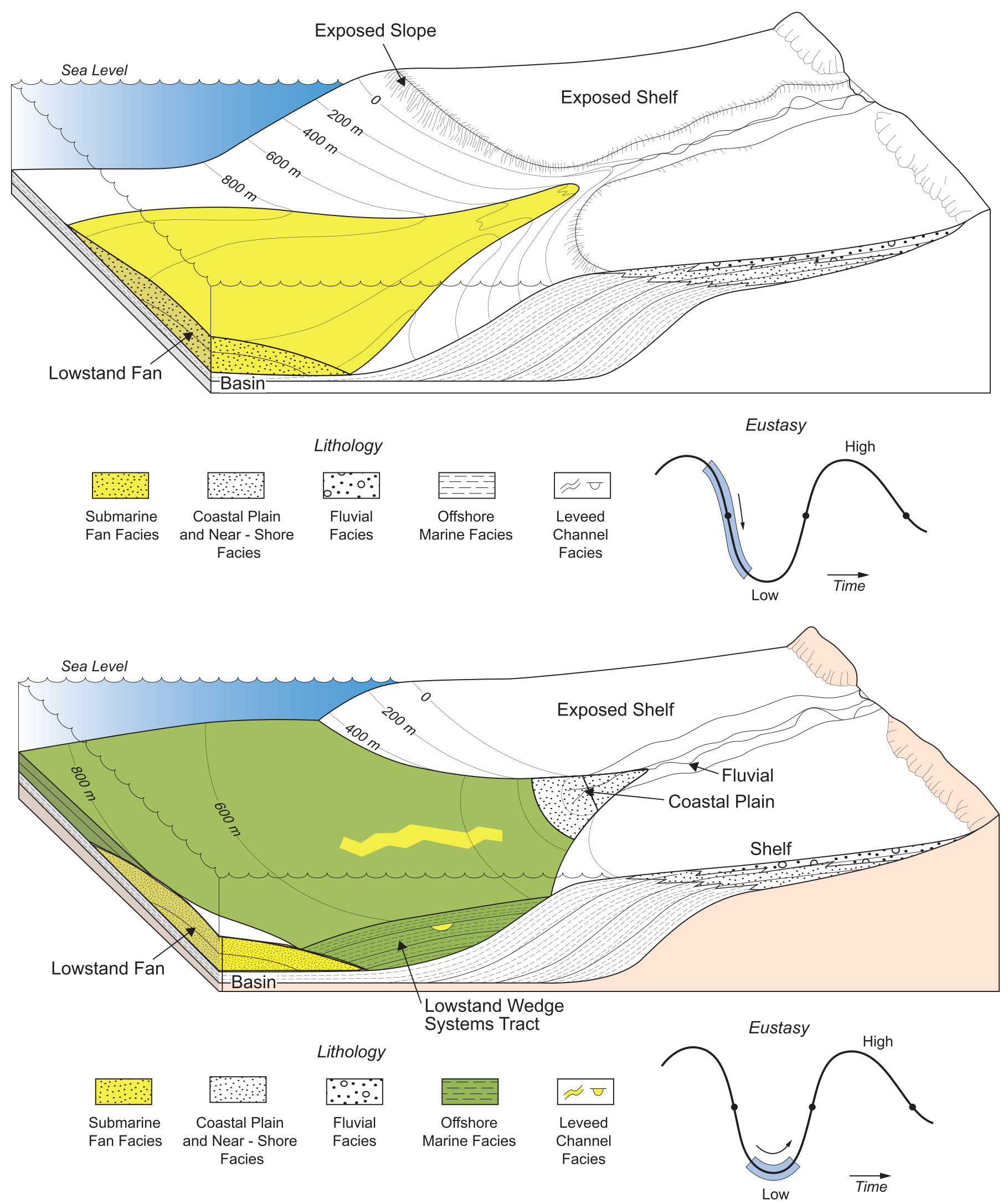

FIG. 1.- Posamentier and Vail (1988) sequence stratigraphic model for the timing of sediment movement from rivers to deep water. This model highlights the importance of exposing the shelf by dropping sea level to connect rivers with submarine fans (upper panel). Their notion that deposition of levees was related to the absolute sea level low as shown in the lower panel has been disproved by more recent work that shows that submarine fans and levees are genetically related and active at the same time. After Posamentier and Vail (1988), their figures 2 and 3. 
Transgression-dominant systems

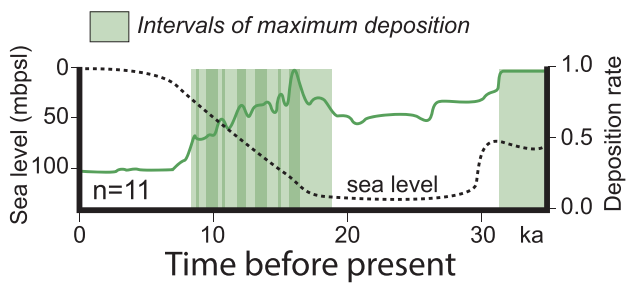

Lowstand-dominant systems

Intervals of maximum deposition

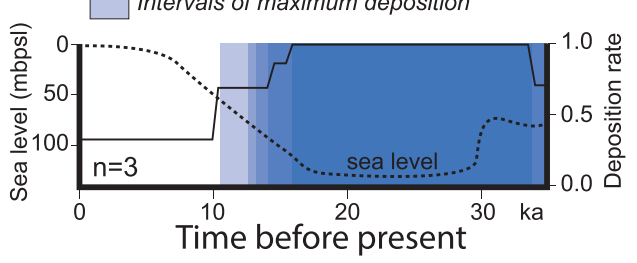

Highstand and sustained systems

Intervals of maximum deposition

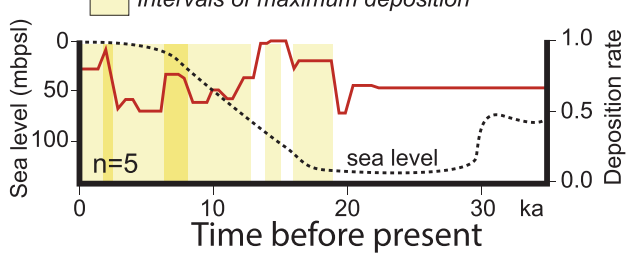

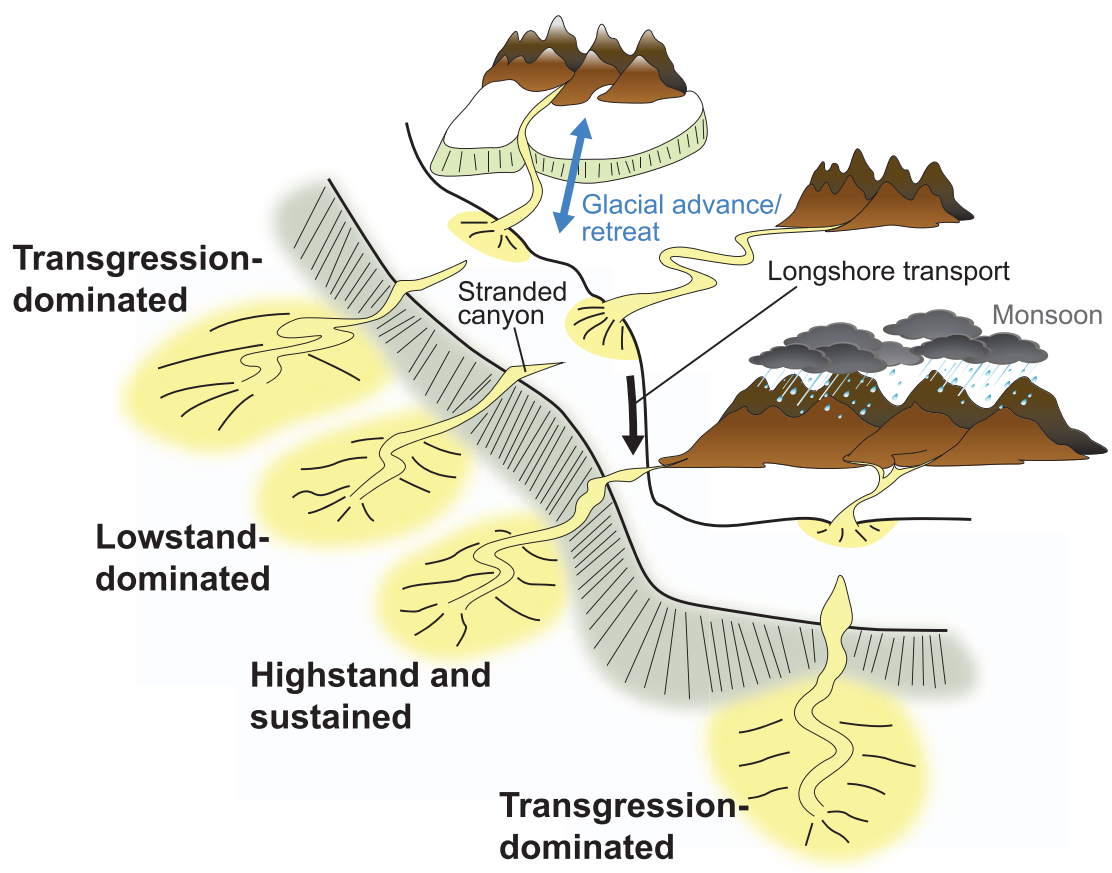

dominated

FIG. 2. - The Covault and Graham (2010) model for sediment delivery to deep water. Plots show periods of maximum deposition (shaded) as a function of sea level for what they define as transgressive, highstand, and lowstand dominated systems. Deposition is also shown as a normalized rate in the light solid line and on the right axis. $\mathrm{N}=$ the number of fans in each class. The schematic depositional model shows the geography of a hypothetical continental margin. From top to bottom: a high-latitude system fed by melt water pulses; a low latitude system with a wide shelf where connection occurs only when sea level is low; a low latitude system with a narrow shelf where connection occurs regardless of sea level; and a low latitude system with maximum sedimentation caused by a shift to a monsoonal climate during sea-level rise. Republished with permission from the Geological Society of America, Covault and Graham (2010), their figures 3 and 4.

$\mathrm{m}$, and within 1 to $4 \mathrm{~km}$ of the shoreline (Stone and Stapor 1996). As closure depth is a function of wave height, larger waves can transport sand farther from the actual shoreline than smaller waves, but measurements of sand distribution on modern shelves (Hallermeier 1981; Howard and Reineck 1981; Palanques et al. 2006) suggest that waves and wavesupported currents are, in general, not capable of moving significant volumes of sediment in the basinward direction across wide shelves.

Sand transport alongshore occurs in cells that include sources for sediment (river mouths, eroding headlands, older inner-shelf sands) and sinks. Most transport cells along depositional coastlines like the Gulf of Mexico have length scales of tens of km (Stone and Stapor 1996), and rates of longshore transport within cells, although inherently difficult to quantify (see Pilkey and Cooper 2002), can exceed 0.075 to $0.15 \mathrm{Mt} / \mathrm{yr}$ (million tons per year). For comparison, this mass of sediments is approximately two orders of magnitude less than the mass of sand delivered to coastal oceans by large rivers like the Mississippi (about 10-30 Mt/yr; Allison et al. 2012; Blum and Roberts 2014), but is likely comparable to the discharge of sand to coastal oceans by many smaller rivers.

Muds, by contrast, are initially transported as plumes from the river mouth, but after reaching the bed, either by plunging or through settling, can be re-entrained by storm waves and other currents, and moved farther across the shelf as fluid muds through a combination of gravitationally driven and wave- and tide-supported currents (Traykovski et al. 2000). Even the mud fraction, however, tends to accumulate in shoreline-parallel bands unless it encounters a submarine canyon (e.g., Hill et al. 2007).

Detailed bathymetric and grain-size data from the California coast (Howard and Reineck 1981) and the Gulf of Lion (Palanques et al. 2006) corroborate this view of coast-parallel nearshore sediment transport (Fig. 4). Data on bathymetry and grain size from the Gulf of Lion indicate that Holocene sand in this area is restricted to water depths of $<30 \mathrm{~m}$ and to distances of $<5 \mathrm{~km}$ from the shoreline, whereas Holocene mud is restricted to water depths of $<100 \mathrm{~m}$ and distances of $<50 \mathrm{~km}$ from the shoreline (Fig. 4). In the Gulf of Lion case, neither the sand or mud fraction of these Holocene sediments impinges on the heads of canyons that fed the currently inactive Rhone Fan (Droz and Bellaiche 1985; Bonnel et al. 2005).

\section{Submarine Canyons: The Connection between Shelf and Deep-Water Systems}

Many previous models for deep-water deposition have stressed the importance of submarine canyons as feeders for sediment to deep water (e.g., Normark 1970; Mitchum 1985; Vail 1987); however, other workers have differentiated line vs. point sources for sediment to feed submarine fans (e.g., Heller and Dickinson 1985; Reading and Richards 1994): line source is used to indicate a broad area of the shelf margin across which sediment transfer would occur, versus a distinct point-source canyon-feeder system. Examination of Quaternary systems, however, shows that all major submarine fans are fed by submarine canyons (Normark and Carlson 2003). Published examples where canyons feed submarine fans, or fed them during the last glacial period, include the Amazon (Damuth and Kumar 1975), the Mississippi (Normark et al. 1986; Weimer 1989), the Zaire (Babonneau et al. 2002), the Bengal (Weber et al. 1997), the Rhone (Droz and Bellaiche 1985), the Indus (Prins et al. 2000), the Nile 

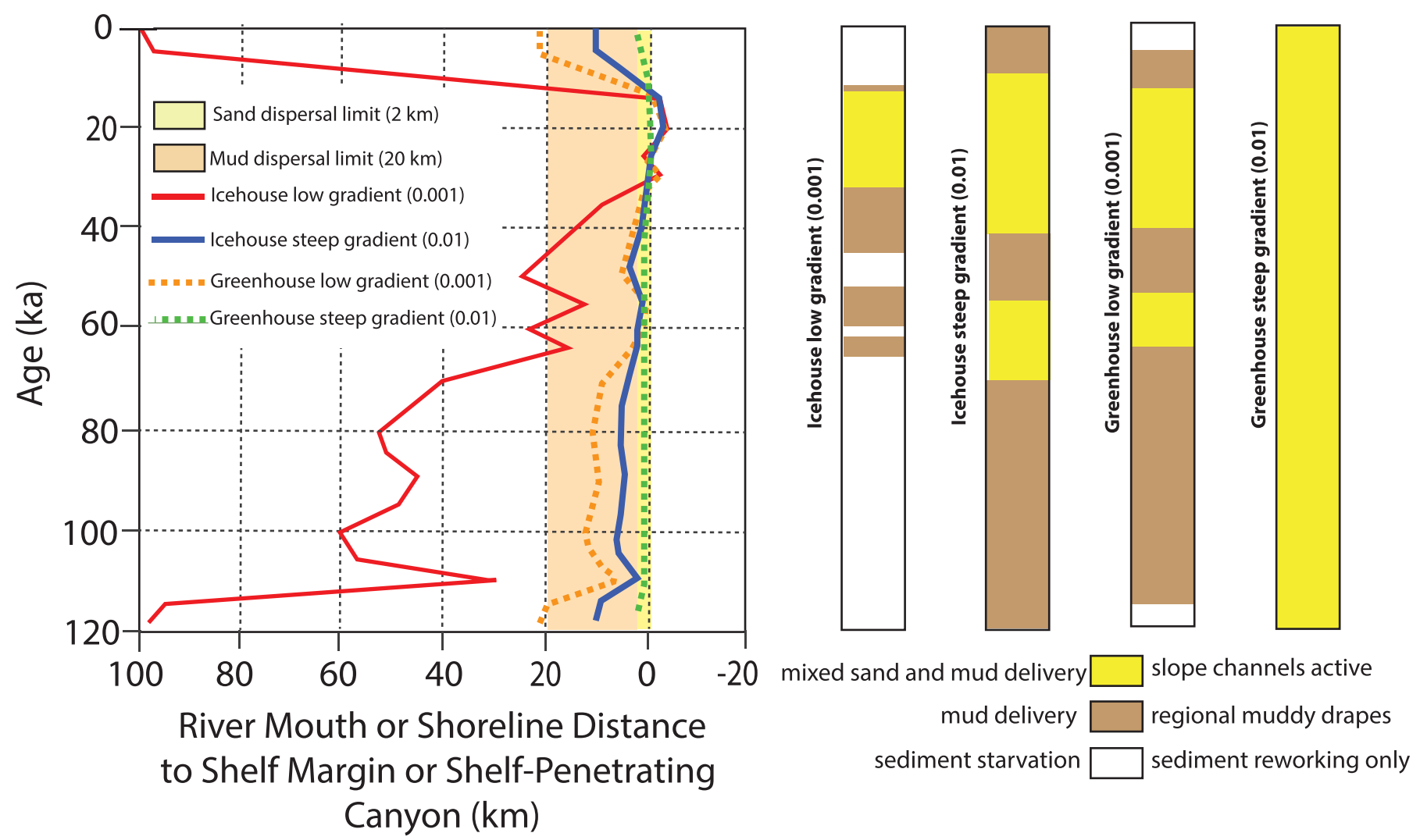

FIG. 3.-Blum et al. (2013) geometric model to illustrate the effects of shelf width and sea-level change on sediment transfer from river mouth to the head of a submarine canyon. The starting point of this figure is the closure depth (i.e., the observation that sand is confined to within a few kilometers of the shoreline and the mud can be advected longer distances across the shelf). The closure depth is shown by the yellow line labeled sand dispersal limit. Given these observations of the conditions needed for sediment transport across the shelf to the canyon head, a range of shelf gradients from shallow passive margin (0.001) to steep active margin (0.01) are provided along with sea-level curves for last $120 \mathrm{ky}$ of glacial eustasy (icehouse) versus an inferred eustatic curve for time periods without large polar ice caps (greenhouse). The figure shows, for example, that for icehouse conditions with a low gradient, mud transfer from river to canyon head would be predicted to occur from about 65 ka until about 15 ka, whereas the canyon head and river would only be close enough for sand to transit between about $30 \mathrm{ka}$ and $17 \mathrm{ka}$. Reprinted from Blum et al. (2013), their figure 33, with permission from Elsevier.

(Ducassou et al. 2009), the Danube (Popescu et al. 2001), the Astoria (Carlson and Nelson 1969; Nelson et al. 2009), the Var (Piper and Savoye 1993), the La Jolla (Covault et al. 2007), and the Golo (Gervais et al. 2006). In some cases there is one long-lived canyon (e.g., the Zaire), whereas in other cases multiple canyons may feed the fan at different times as fluvial avulsion and delta-lobe switching changes the location of pointsource sediment input (e.g., the Gulf of Lion, Berné and Gorini 2005). Given that fans are fed by canyons, by definition a point source, we differentiate sediment transferred to the canyon head from a longshore drift system vs. that transferred directly from a river mouth.

We also note that data on Quaternary systems suggest that the excavation of canyons is not, in and of itself, a significant contributor of sediment to submarine fans. Normark and Carlson (2003) observed that the ratio of canyon area to the area of their associated fans ranges from $0.15 \%$ to $17 \%$ with an average of $4 \%$. To further examine this issue, we calculated canyon volume for the Bengal Fan "Swatch of No Ground," the Danube, and the Monterey canyons, where we had adequate bathymetric data and river-discharge data. The modern sediment discharge from these rivers and longshore-drift systems could fill their canyons in 400 to 2000 years (Table 1), even with sediment flux that is much reduced from their pre-Industrial levels by dams and other human activities. In the same way that previous studies have shown the excavation of incised valleys provides a sediment volume that is only 5 to $10 \%$ of the normal flux through the system (e.g., Burgess and Hovius 1998; Blum and Törnqvist 2000; Blum et al. 2013), our new data show that canyons act as conduits, but their excavation does not materially contribute to the growth of submarine fans. Hence, the direct flux of sediment from hinterland source terrains through the fluvial feeder system, rather than recycling of previously stored sediments, accounts for the overwhelmingly greater part of sediment necessary for the growth and development of deep-water depositional systems.

\section{Factors Thought to Control Sediment Transfer to Deep Water}

Research on sediment transport to deep water over the last 50 years has identified a number of controls on when large volumes of sediment can be transported to deep water.

Sea Level.-It is well documented that many large fans like the Mississippi (Normark et al. 1986), Amazon (Milliman et al. 1975; Normark et al. 1997), Nile (Ducassou et al. 2009), and Rhone (Bonnel et al. 2005) are currently mantled with pelagic ooze, and that active deposition ended as global sea level began to rise 15 to $20 \mathrm{kyr}$ ago. Sealevel positions below $-100 \mathrm{~m}$ would put the shoreline proximal to the heads of these canyons. With relative sea-level fall, rivers extend their courses across emergent shelves and transport sediment to shorelines on the outer shelf, to what was referred to as the staging area (Posamentier and Kolla 2003), where marine processes can disperse them to the heads of submarine canyons. Hence, it is clear that relative sea-level change 


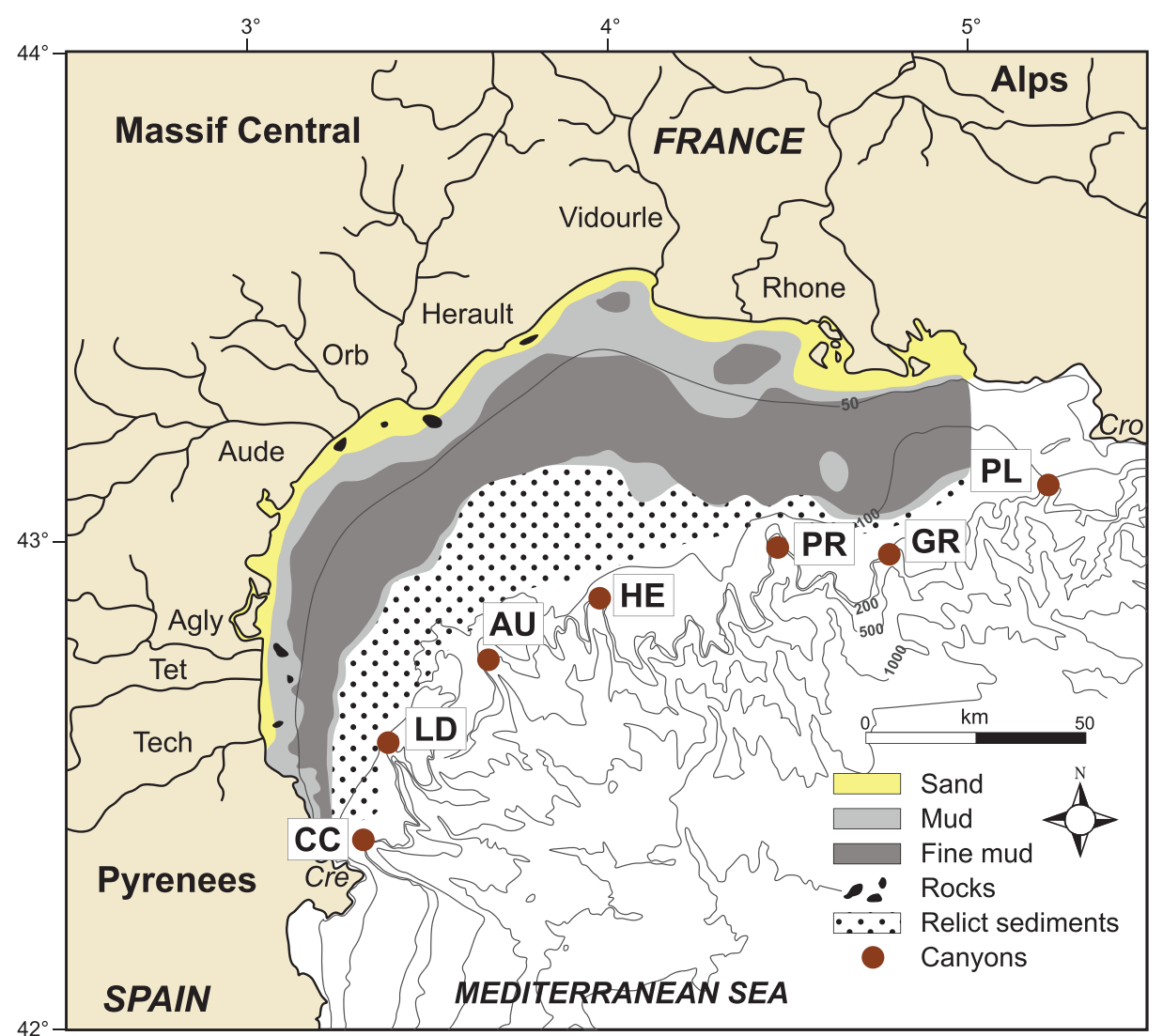

FIG. 4.-Map showing the distribution of bottom sediment observed in the Gulf of Lion, northern Mediterranean Sea. Water depth contours are in meters. Note that sand (yellow) is restricted to a narrow band near the shore and that none of the Holocene sediment impinges on the heads of the submarine canyons (CC, Cap de Creus; LD, Lacaze-Duthiers; AU, Aude; HE, Herault; PR, Petite Rhone; GR, Grand Rhone; PL, Planier) in this area. Reprinted from Palanques et al. (2006), their figure 1, with permission from Elsevier. exerts an important control on when sediment can move from near shore to deep water, by forcing cross-shelf transit of river mouths and shorelines.

Shelf Width.-Walsh and Nittouer (2003), Blum and Hattier-Womack (2009), Warrick and Farnesworth (2009), and Normark et al. (2009) proposed that shelf width exerts a major control on the quantity and caliber of sediment that is transferred from coastal to deep-water environments. Fans associated with wide shelves, typically in passive-margin systems like the Mississippi and Amazon, are currently undergoing slow rates of pelagic deposition. In contrast, fans along active tectonic margins with narrow shelves, like those on the California coast (Covault et al. 2007) and the Var Fan in the Mediterranean (Piper and Savoye 1993), have been shown to be sites of significant deposition at present. Walsh and Nittouer (2003) presented data on shelf width, sediment flux, and the percentage of sediment bypassed to deep water (Fig. 5). They demonstrated a correlation between shelf width and sediment supply and observed that, in modern interglacial highstand conditions, a higher percentage of sediment was transferred to deep water along coastlines with narrow shelves. However, the link between deep-water deposition and shelf width or tectonic setting is not simple. The Zaire Fan is an example of a passive margin fan with a broad shelf that is presently active (Khripounoff et al. 2003). In this case the fixed location of the Congo River is thought to have allowed the Zaire Canyon to cut headward across the shelf though several sea-level cycles since the Pliocene (Babonneau et al. 2002). Observations such as these suggest that shelf width is an important boundary condition, but at a more fundamental level, the distance between the canyon head and shoreline is a better indicator of the likelihood of sediment transfer to deep water than shelf width alone.

Climatically Driven Changes in Sediment Flux.-Even where a connection could occur due to relatively low sea-level positions, or proximity of the shoreline to a canyon head, sediment delivery to deep water may be supply-limited. For example, during the Last Glacial Maximum, aridity in the Nile drainage basin resulted in reduced sediment flux to deep water compared to the later period of rising sea level, when

TABLE 1.-The volume of three submarine canyons compared to the sediment discharge of the rivers feeding them. River discharge was cited in terms of tonnes/year. Converted to $\mathrm{m}^{3}$ assuming a density of $2.65 \mathrm{~g} / \mathrm{cm}^{3}$. To determine the volume of sediment that was evacuated to form the canyon (sediment volume of canyon) the canyon volume was measured using bathymetric data. Seventy percent of this volume was assumed to be sediment (the remaining thirty percent is assumed to be porosity).

\begin{tabular}{|c|c|c|c|c|}
\hline River/Canyon/Fan & $\begin{array}{l}\text { Sediment Volume } \\
\text { of Canyon }\left(\mathrm{m}^{3}\right)\end{array}$ & $\begin{array}{l}\text { Sediment Discharge from River } \\
\text { and Longshore Drift }\left(\mathrm{m}^{3} / \mathrm{yr}\right)\end{array}$ & $\begin{array}{l}\text { Years for River to Discharge } \\
\text { the Volume of the Canyon }\end{array}$ & References \\
\hline Ganges Swatch of No Ground/Bengal & $400 \times 10^{9}$ & $2 \times 10^{8}$ & 2000 & Goodbred 2003 \\
\hline Danube/Viteaz/Danube & $24 \times 10^{9}$ & $2 \times 10^{7}$ & 1200 & Panin and Jipa 2002 \\
\hline Salinas River and longshore drift Monterey & $2 \times 10^{8}$ & $5 \times 10^{5}$ & 400 & Paull et al. 2005 \\
\hline
\end{tabular}




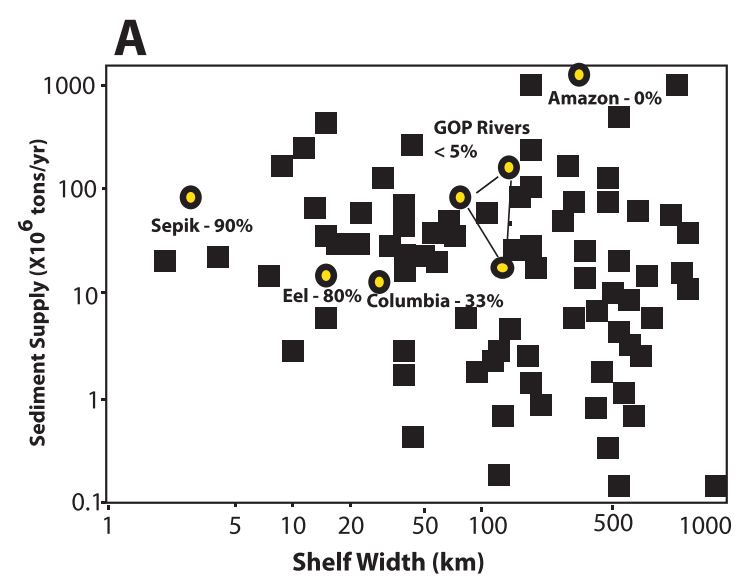

climate in the headwaters of the Nile was wetter (Ducassou et al. 2009). Similarly, low sediment flux on the Toyama Fan off of Japan was observed during the Last Glacial Maximum due to cold, arid conditions in the source area. Sediment flux increased from ca. 18 to $7 \mathrm{ka}$ as the climate became wetter (Nakajima et al. 2009). Similar patterns of onshore aridity affecting deep-water sediment flux during low stands of sea level were observed in the California Borderlands by Covault et al. (2010).

Subsidence of the Shelf.-From interpretations of ancient strata, a number of workers (Jervey 1988; Posamentier and Vail 1988; Posamentier and Kolla 2003) propose that rapid subsidence across the shelf could act to trap sediment in shallow marine environments and prevent its transfer to deep water. For example, in the Gulf of Mexico basin, the Oligocene is known as a time of rapid growth-fault development along the shelf margin, which has long been interpreted to have trapped large volumes of sediments, and, by inference, reducing flux to the deeper basin (Brown et al. 2004). Numerical models of subsidence on continental margins by Reynolds et al. (1991) suggest that high rates of subsidence on the shelf should result in narrow continental shelves; lower rates of subsidence were related to wider shelves. This result suggests that high subsidence rates could correlate to higher sediment flux to deep water as shelf width is inversely correlated to high sediment flux to deep water (Fig. 5). In the modern world, shelf width scales to the size of feeder river systems (Blum et al. 2013), which suggests that the synoptic shelf width is fundamentally a reflection of surface processes, and subsidence plays a very subordinate role. Regardless, our interest here is a process-based linkage over a short time scale, and to our knowledge there are not adequate data over these timescales to more rigorously address the effects of subsidence on sediment movement to deep water.

\section{METHODS}

To test the hypothesis that shelf width, or the distance between canyon head and shoreline, exerts a strong control on the movement of sediment from near-shore to deep-water environments, we mined published literature for twenty-five submarine canyons to compile data on the grain size of sediments observed on the sea floor (Fig. 6; Table 2) (from cores, submersible dives, and multi-beam images), age of surficial deposits, evidence of sediment movement from repeated multi-beam surveys or current monitors, sediment source (direct fluvial-deltaic feed versus longshore drift), and sediment flux. We also measured distance from the canyon head to the shoreline from published maps or Google Earth ${ }^{\mathrm{TM}}$, and distinguished three types of systems: 1) longshore-drift-fed systems, where we measured the distance from the canyon head to the shoreline (Fig. 7A); 2) river-fed systems, where we measured distance between a single river mouth and the canyon head (Fig. 7B); and 3) delta-fed systems with multiple distributary channels, where we measured the distance from the head of the canyon to the nearest point on the shoreline of the subaerial delta plain (Fig. 7C). We restricted this study to canyons where core data

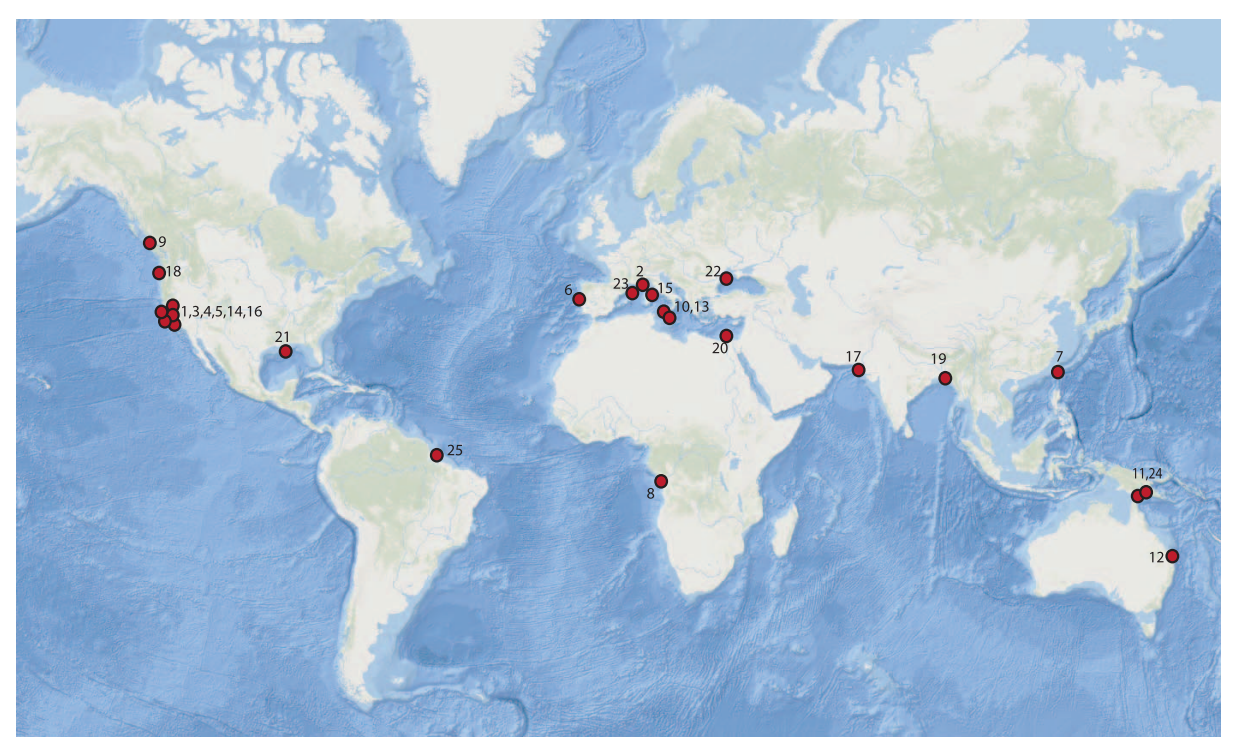

FIG. 6.- Location of the studies of Quaternary submarine canyons and fans used in our analysis. The numbers on the map correspond to the numbers in Table 2 to allow a cross-reference of fan name, data, and location. Image from ESRI Ocean Basemap. 
TABLE 2.-Data on submarine canyons used in this study showing canyon head to shoreline distance measured from GoogleEarthTM or published bathymetric maps, grain size of sediment at the sea floor from cores, source of sediment feeding canyon, and published estimates of the percentage of sediment provided from river and alongshore drift that was moved down the canyon to deep water.

\begin{tabular}{|c|c|c|c|c|c|c|}
\hline & Fan or Canyon & $\begin{array}{c}\text { Canyon Head } \\
\text { to Shoreline } \\
\text { Distance }(\mathbf{k m})\end{array}$ & Dominant Grain Size & Sediment Source & $\begin{array}{c}\text { Estimate Percentage } \\
\text { of Sediment Moved } \\
\text { to Deep-Water }\end{array}$ & Reference \\
\hline 2 & Var & 0.3 & Pebble, cobbles, sand, mud & $\begin{array}{l}\text { River feeds into canyon } \\
\text { head }\end{array}$ & 90 & Mulder et al. 1998 \\
\hline 4 & Redondo & 0.5 & Sand & Longshore drift & 53 & Normark et al. 2009 \\
\hline 5 & La Jolla & 0.8 & Fine gravel to fine sand & Longshore drift & unknown & Paull et al. 2013 \\
\hline 6 & St Nazare & 1.0 & Silt with subordinate sand & Longshore drift & unknown & $\begin{array}{l}\text { Oliveira et al. 2007; } \\
\text { Stigter et al. } 2007\end{array}$ \\
\hline 7 & Kao-ping & 1.0 & Mud with sand & $\begin{array}{l}\text { River feeds into canyon } \\
\text { head }\end{array}$ & unknown & Liu et al. 2002 \\
\hline 10 & Gioia and Mesima & 1.0 & Sand & Delta at head of canyon & unknown & $\begin{array}{l}\text { Gameri and Marani } \\
2008\end{array}$ \\
\hline 11 & Sepik River & 3.0 & Mud and silt, $<25 \%$ sand & $\begin{array}{l}\text { River mouth near head } \\
\text { of canyon }\end{array}$ & 90 & $\begin{array}{l}\text { Walsh and Nittrouer } \\
2003\end{array}$ \\
\hline 12 & Fraser Island & 5.0 & Fine sand & $\begin{array}{l}\text { Waves and tides move } \\
\text { sediment into head of } \\
\text { submarine canyon }\end{array}$ & unknown & Boyd et al. 2008 \\
\hline 13 & NW Sicily & 5.0 & Calcareous ooze & No present direct source & unknown & $\begin{array}{l}\text { Gameri and Marani } \\
2008\end{array}$ \\
\hline 14 & Oceanside & 7.6 & Calcareous ooze & $\begin{array}{l}\text { Strong littoral cell. } \\
\text { Relatively wide shelf }\end{array}$ & unknown & $\begin{array}{l}\text { Covault et al. 2007; } \\
\text { Normark et al. } 2009\end{array}$ \\
\hline 15 & Golo & 10.0 & Calcareous ooze & No present direct source & unknown & Gervais et al., 2006 \\
\hline 16 & Eel & 10.0 & $\begin{array}{l}\text { Silt, dominent, clay, and } \\
\text { fine sand }\end{array}$ & $\begin{array}{l}\text { Fluidized mud moved } \\
\text { across shelf from Eel } \\
\text { R. }\end{array}$ & 52 to 80 & $\begin{array}{l}\text { Walsh and Nittrouer } \\
\text { 2003; Hill et al. } \\
\text { 2007; Warrick } 2014\end{array}$ \\
\hline 20 & Nile & 37.0 & Calcareous ooze & No present direct source & 0 & Ducassou et al. 2009 \\
\hline 21 & Mississippi & 43.0 & Calcareous mud & No present direct source & 0 & Normark et al. 1986 \\
\hline 22 & Danube & 100.0 & $\begin{array}{l}\text { Laminated coccolithic } \\
\text { mudstone or sapropelic } \\
\text { mudstone }\end{array}$ & No present direct source & unknown & Popescu et al. 2001 \\
\hline 23 & Rhone & 114.0 & Calcareous mud & $\begin{array}{l}\text { Med sand c. } 8 \text { ka. } \\
\text { Collapse of upper } \\
\text { slope or fed by other } \\
\text { canyons? }\end{array}$ & unknown & Bonnel et al. 2005 \\
\hline 24 & Fly & 170.0 & $\begin{array}{l}\text { Bioturbated calcareous } \\
\text { mustone }\end{array}$ & No present direct source & 0 & $\begin{array}{l}\text { Walsh and Nittrouer } \\
2003\end{array}$ \\
\hline 25 & Amazon & 300.0 & Foraminiferal-rich clays & No present direct source & 0 & Normark et al. 1997 \\
\hline
\end{tabular}

are available to determine the grain size and age of sediment at the floor of the most recently active parts of the canyon, and excluded published studies that were solely based on interpretations of seismic data. In looking at reported grain-size data, we paid special attention to the coarsest fraction. Nonetheless, our examples cover a wide range of systems from narrow shelves and comparatively small canyons and fans like the Var and Golo in the Mediterranean, to very large passive-margins systems such as the Mississippi and Amazon (Fig. 6, Table 2). 

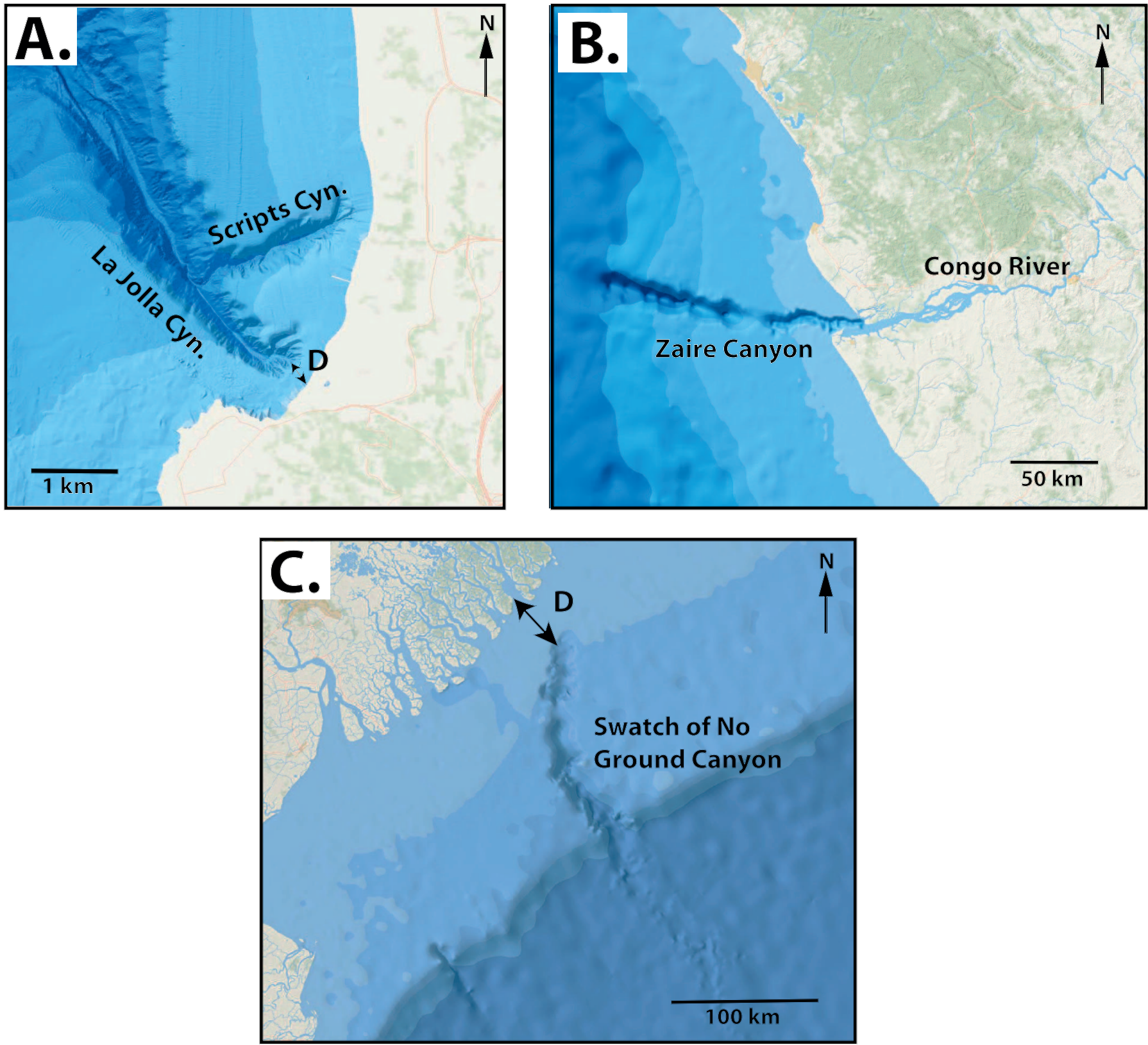

FIg. 7.-Examples of how distances from canyon head to shoreline were measured in this report. A) Longshore-drift-fed system (La Jolla Canyon, California). Double arrow (D) shows canyon to shoreline transect. B) Direct river-fed system (Congo River/Canyon, Angola). C) Delta-fed system (Ganges Delta, India). Double arrow (D) shows distance from canyon to shoreline. All images are from ESRI Ocean Basemap.

These data have clear limitations. Compared to modern fluvial or deltaic systems, sampling in submarine canyons and fans is very sparse due to greater costs and operational difficulties. Because of the difficulty in getting core data, geochronological data are more limited than in modern studies of terrestrial and nearshore environments. It can be less clear which parts of the canyon are active, as it is difficult to make direct observations during turbidity current flows. In some cases, like the Mississippi and the Bengal systems, core data were available only from the upper fan channels. Some systems like the Var, Monterey, and La Jolla are extremely data rich with numerous cores, current-meter data, repeated multi-beam surveys, and detailed mapping with submersibles. In other cases, like the Bengal Fan, we had access to more limited bathymetric data, and sparse core or 2D seismic data. Given the limitations of the data that are available, we chose examples that had the minimum of data needed to answer our research questions, but also gave us a wide geographic spread (Fig. 6).

\section{RESULTS}

Plotting the distance from canyon head to the shoreline vs. the four grain-size bins (gravel, sand, silt to clay, calcareous mud) reveals a consistent trend between distance from canyon head and the grain size of the youngest sediment in the axes of these canyons (Table 2; Fig. 8). Of the twenty-five canyons in the study, sixteen (64\%) show evidence of late 


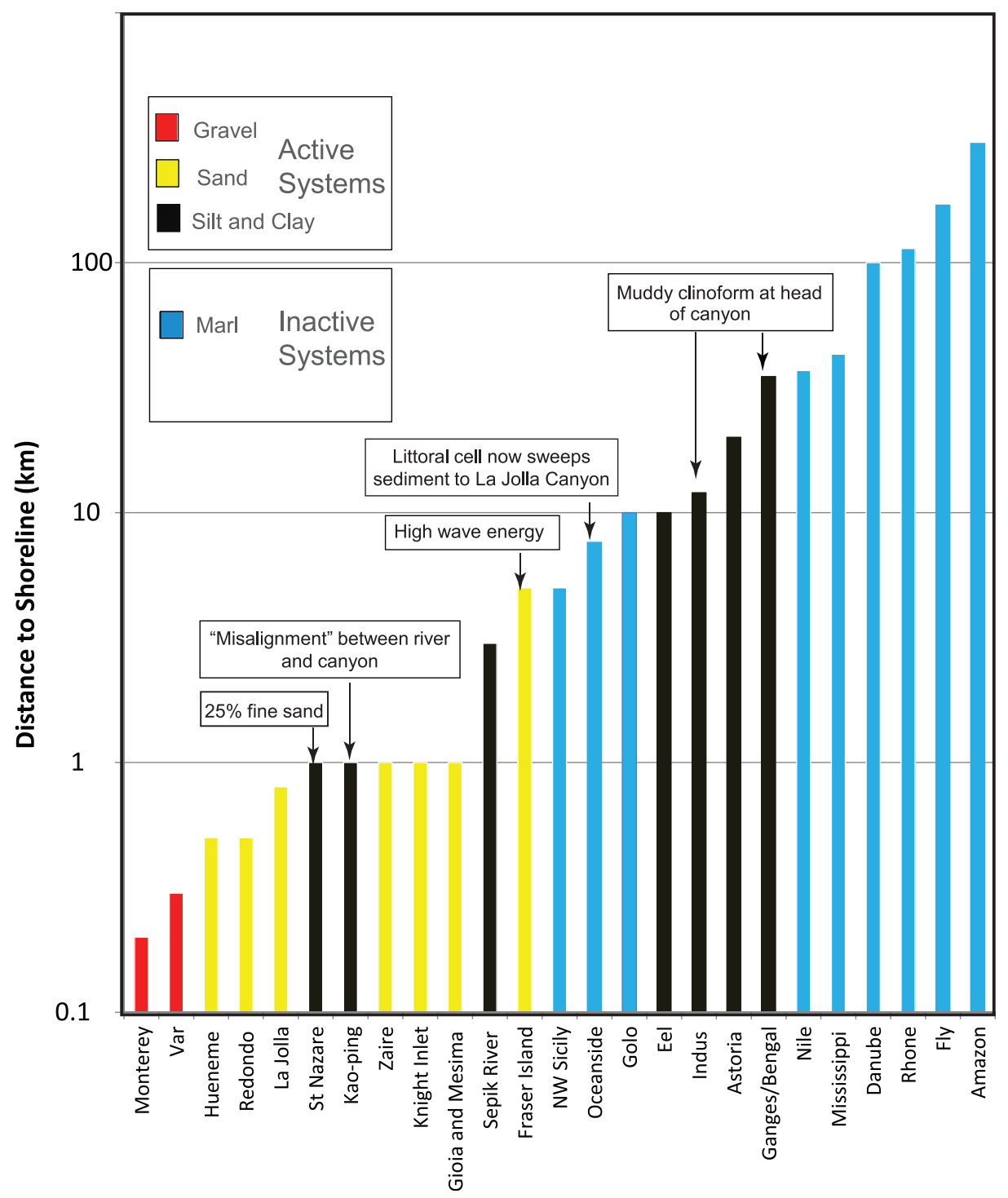

FIG. 8.-Distance in kilometers from shoreline to head of canyon for canyons used in this study (logarithmic scale). Canyons are color coded by the dominant lithology of Holocene sediments in the most active part of the canyon.
Holocene sediment movement and nine (36\%) are mantled by calcareous sediments and considered inactive. Although limited data are available from the literature on the percentage of sediment that is transferred from fluvial, deltaic, and littoral systems to deep water, these data support the view that net sediment transfer to deep water is a function of the distance from canyonhead to shoreline (Figs. 8, 9, Table 2).

\section{Gravel-Floored Canyons}

Two canyons in our dataset are characterized as active with gravel-size sediment known to have been transported during the period of historical monitoring. The Var River in southern France is a high-gradient stream with headwaters in the Alps, and a river mouth that discharges coarsegrained sediment almost directly into the head of the Var Canyon, which is less than $300 \mathrm{~m}$ from the shoreline (Mulder et al. 1998; Savoye et al. 1993). Fresh, gravelly sediment waves have been observed by submersible dives within the canyon, and are visible on back-scatter images of the canyon floor: some of these waves are composed of blocks of concrete from the 1978 Nice airport collapse (B. Savoye, oral communication 2007).
Moreover, large sediment gravity flows have been documented in association with spring floods (Mulder et al. 1998).

For the Monterey Canyon, Paull et al. (2005) used vibracores and submersible dives to document abundant pebble to cobble-size clasts and sand that mantle the floor of the upper canyon, and showed that 50 to $80 \%$ of the upper canyon floor is covered by this coarse-grained sediment. The canyon head comes within 0.1 to $0.2 \mathrm{~km}$ of the shoreline (Table 2), sand is fed into the upper reaches of the canyon primarily by longshore drift with subordinate direct fluvial input (Smith et al. 2005), and current meters indicate that turbidity flows competent to transport sand in Monterey Canyon are commonly triggered by winter storms (Paull et al. 2003).

\section{Sand-Floored Canyons}

Seven canyons in our dataset are floored primarily with sand (Table 2). For this group, the distance from canyon head to shoreline ranges from 0.8 to $5 \mathrm{~km}$ from the shoreline. Five of these canyons (La Jolla, Huememe, Redondo, and Fraser Island) are fed primarily by longshore drift, one (the Zaire) is fed by direct river discharge into the head of a long-lived canyon 


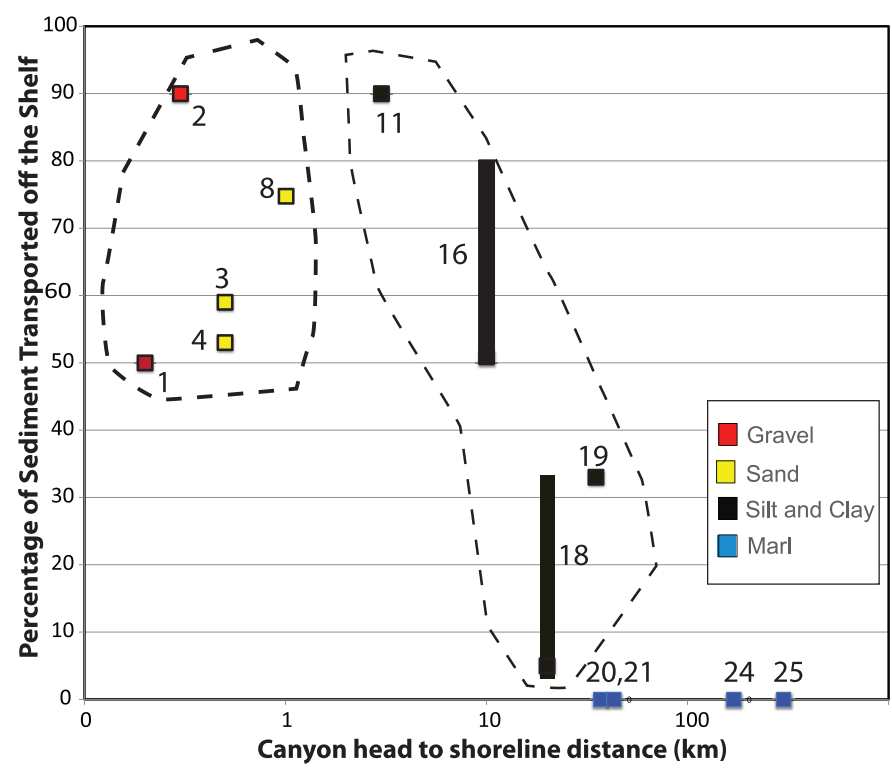

FIG. 9.-Cross-plot of the percentage of sediment transferred from the shelf to deep water as a function of distance from canyonhead to shoreline. Numbers refer to canyons in Table 2. Dominant grain size is color coded. In the case of the Eel (16) and the Astoria-Columbia (18) we have shown a range as different studies have reported different values for the percentage of sediment transferred to deep water.

that has cut headward across the shelf into the estuary, and three (Gioia and Mesima canyons and the Knight Inlet) are fed by deltas. Fraser Island is the canyon farthest from the shore at $5 \mathrm{~km}$. In this system, strong longshore currents move sand to the tip of a spit and the canyon lies $5 \mathrm{~km}$ from that point. Current meters and sediment traps show that sand deposition from turbidity currents is ongoing in the Zaire Canyon (Khripounoff et al. 2003; Cooper et al. 2013). Repeated multi-beam surveys show significant sediment movement at Knight Inlet (Conway et al. 2012). Radiocarbon dating of associated plant debris in La Jolla Canyon (Paull et al. 2013) and OSL dating of sands offshore Fraser Island (Boyd et al. 2008) show that in these canyons there is active sediment transfer during the very late Holocene.

\section{Mud-Floored Canyons}

For seven canyons in our dataset (St Nazare, Kao-Ping, Sepik, Eel, Indus, Astoria, and Bengal), Holocene sediment is primarily clay and silt. The distance from shoreline to canyon heads ranges from 1 to $35 \mathrm{~km}$ (Fig. $10)$.

Within this group, the short, high-gradient Kao-Ping River in Taiwan is distinct, because the canyon head is within $1 \mathrm{~km}$ from the shore, and the Kao-Ping River discharges sediment during storms with concentrations sufficient to generate mud-rich hyperpycnal flows directly to the canyon, while much of the sand fraction is reworked by a strong littoral cell and moved away from the canyon (Liu et al. 2002). Hence, even though modern deposits in the canyon are mud rich, there is also a significant sand component. In the case of the St Nazare, the dominant grain size at the seafloor is mud, but parts of the upper canyon mantled with silty sand and turbidity-current-derived sands less than 150 years old are found below a thin layer of mud in other parts of the canyon (Stigter et al. 2007).

In contrast, the Indus and Ganges-Brahmaputra deltas have active, muddy, subaqueous clinoforms that reach the heads of their respective canyons (Currie et al. 2002; Clift et al. 2014; Rogers et al. 2015), which have eroded headward and now penetrate $100 \mathrm{~km}$ or more into the shelf. Based on calculation of sediment flux, Goodbred (2003) estimated that two-thirds of the sediment load of the Holocene Ganges River is trapped in the delta and delta plain, and 1/3 passes down the "Swatch of No Ground" Canyon onto the Bengal Fan, which is known to have been active throughout the Holocene (Weber et al. 1997). In the Eel River case, clay and silt is transported within the littoral cell to the head of Eel Canyon (Hill et al. 2007), and turbidity currents have been observed within the canyon itself: Hill et al. (2007) estimate that 50 to $80 \%$ of the clay- and silt-size sediment supplied by the Eel River during the period of measurement has been transported through Eel Canyon to the deep-water basin.

In our dataset, the single most common connection for sediment transfer is where canyon heads intersect a longshore-drift system. This scenario occurs in $46 \%$ of the examples. Direct fluvial input into the head of a canyon occurs in $27 \%$ of examples, whereas connection between a delta and the head of the canyon (including muddy subaqueous deltas) occurs in $27 \%$ of examples, hence a direct fluvialdeltaic connection comprises $54 \%$ of the sample dataset. The large number of longshore-drift sources may be due to sampling bias towards the well-studied systems of the California Borderlands, where there are narrow shelves, strong longshore currents, and canyons that penetrate across the narrow shelf into longshore-drift cells. This could also be a scenario that is more common when sea level is high, and canyons are already well established, such that headward erosion makes it more likely to intersect a longshore-drift source rather than a specific rivermouth or deltaic source. It may also be more likely that, during periods of low sea level like the Last Glacial Maximum, direct connections between canyons and river mouths, or a broader deltaic distributary system, were more common. As argued by Pratson and Coakley (1996), loading of the shelf margin by fluvial deltaic sediments may be the primary mechanism by which canyons are initiated then grow headward. In fact, we envision a common scenario to be initiation of canyons during cross-shelf extension of river mouths in response to sea-level fall, with initial loading of the margin from muddy delta-front clinothems, followed by headward growth of canyon heads and intersection of river mouths or longshore-drift cells. Canyons are maintained as conduits as long as sand is delivered to the canyon head, but are then eventually filled by mud when the sand supply is removed (e.g., Walsh et al. 2007).

\section{Inactive Systems}

Nine of the canyons (NW Sicily, Oceanside, Golo, Nile, Mississippi, Danube, Rhone, Fly, and Amazon) in our database are characterized by deposition of a thin veneer of carbonate-rich mudstone or ooze, which suggests very low rates of clastic influx. In these cases, distances from canyon head to shoreline range from $5 \mathrm{~km}$ to $300 \mathrm{~km}$. Three canyons form small and steep systems, the Golo (Corsica), Oceanside (California), and NW Sicily, are $<10 \mathrm{~km}$ from the shoreline; in the Oceanside case, a littoral cell transports sediment away from the canyon head (Normark et al. 2009). The other inactive canyons are linked to relatively large, lowgradient fluvial systems with broad shelves (Rhone, Nile, Mississippi, Danube, and Amazon), where the river mouths are now 35 to $300 \mathrm{~km}$ from canyon heads.

The Amazon case is particularly informative. Bathymetry of the modern Amazon shelf shows that the canyon head is at a current water depth of $-100 \mathrm{~m}$ and that the mouth of the Amazon River is separated from the canyon by a broad, shallow shelf (Fig. 10). Milliman et al. (1975) initially recognized that sediment delivery to the Amazon fan "turns on and off" as sea level falls below, and rises above, -40 to $-60 \mathrm{~m}$ during glacio-eustatic cycles (see also Maslin et al. 2006): this depth essentially corresponds to the foreset-bottomset break of the Holocene subaqueous muddy clinothem (Nittrouer et al. 1986), which now extends $>100 \mathrm{~km}$ across the shelf from the actual subaerial shoreline, but is still about $75 \mathrm{~km}$ from the canyon head. Hence sea-level fall to positions below -40 to $-60 \mathrm{~m}$ would result in 

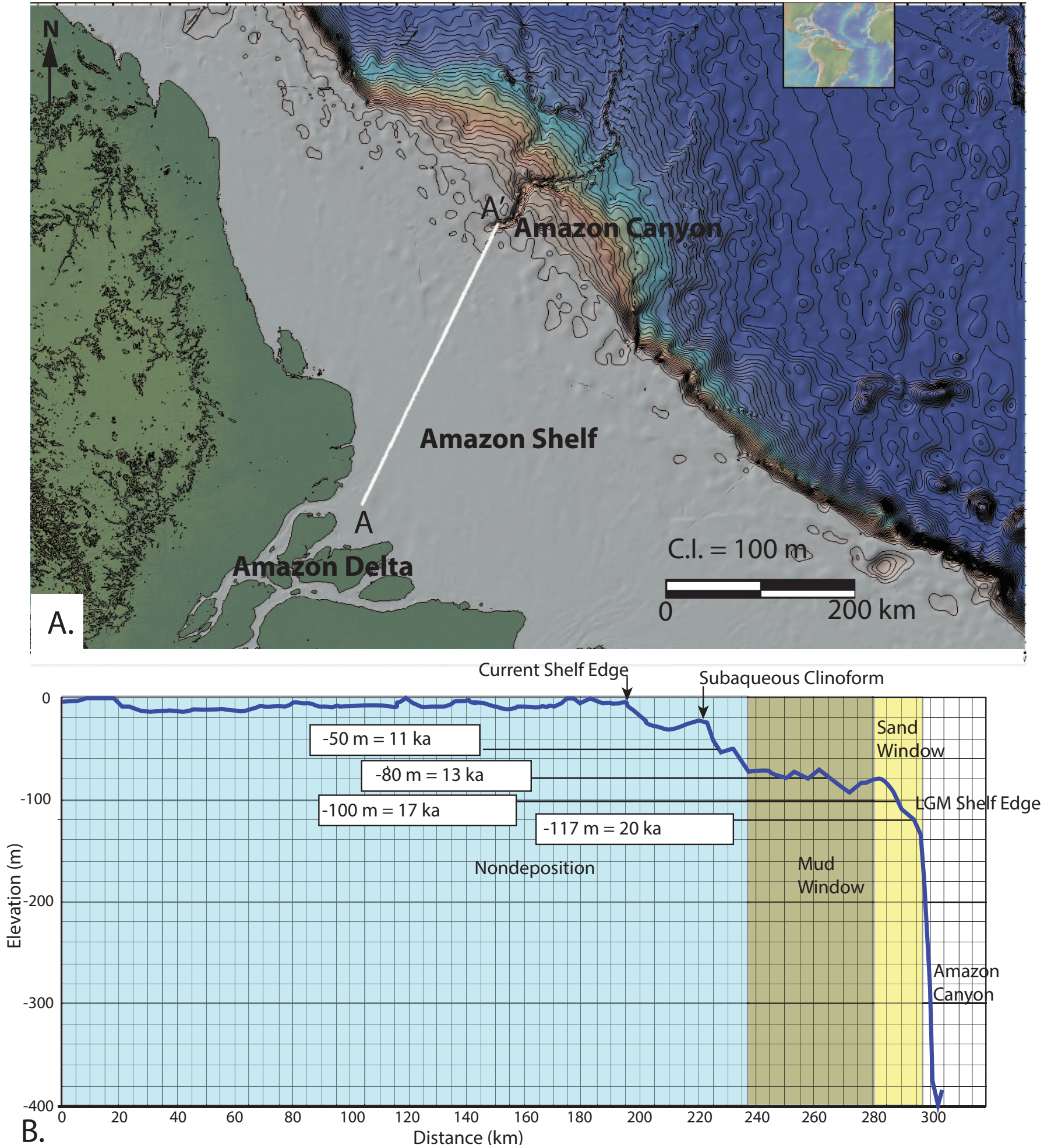

FIG. 10.-A) Bathymetric map for the modern Amazon Shelf. B) Bathymetric cross section showing depth and timing of most recent sea-level rise from the sea-level curve of Siddall et al. 2003. Bathymetric data were generated using the Global Multi-Resolution Topography (Ryan et al. 2009) using GeoMapApp http://www.geomapapp.org/.

progradation of the broad muddy subaqueous clinothem foreset to the shelf margin, connection of the muddy faction of sediment discharge to the canyon head, and a "turning on" of the Amazon fan. However, the more concentrated mixed sand and mud fraction associated with the river mouth would not connect until sea level was very low, and the river mouth was very close to the canyon head. Radiocarbon dating of sediments in the Amazon Fan channels indicates that the maximum rates of extension of the channel-levee system occurred between $22 \mathrm{ka}$ and $16 \mathrm{ka}$ (Maslin et. al. 2006), which corresponds to the last glacial maximum, when global sea level was at $-90 \mathrm{~m}$ or lower (Siddall et al. 2003; Peltier and Fairbanks 
2006), and presumably when sand was being delivered to the canyon head. Fan shut-off then occurred at about $12 \mathrm{ka}$ when sea-level rose to about -50 $\mathrm{m}$ (Maslin et. al. 2006).

Based on our analysis of the distance that mud and sand can be transported across the shelf, we would predict that sand deposition on the Amazon would have ended between ca. 17 to $13 \mathrm{ka}$ when sea level rose above $-80 \mathrm{~m}$ : mud deposition would have been reduced by ca. $13 \mathrm{ka}$ when sea level rose to $-80 \mathrm{~m}$, then ceased by the time sea-level rose to $-50 \mathrm{~m}$ at ca. $11 \mathrm{ka}$ (Fig. 10). Hence, for a system with a wide shelf like the Amazon, the connection time for sand transport, and maximum rates of sediment discharge to canyons, will be inherently brief and correspond to sea-level positions at the shelf margin. For the last $100 \mathrm{ka}$ glacial-interglacial period, sand transfer and deposition would have occurred for $<10 \%$ of the total time interval.

\section{DISCUSSION}

Data that we have presented suggest that close proximity between canyon head and shoreline ( $<500 \mathrm{~m}$ for gravel, $<2 \mathrm{~km}$ for sand, $<40 \mathrm{~km}$ for mud) is a necessary condition for sediment transfer from fluvial-deltaic systems to deep water. This connection can be driven by eustatic fall, but it can also occur in tectonically active margins where the shelf is narrow (e.g., the California Borderlands), or on passive margins where a long-lived canyon has cut headward across a broad shelf (e.g., the Congo River-Zaire Canyon, the Swatch of No Ground Canyon of the Bengal system). The possibility also exists for deltas to build across the shelf and make a connection with submarine canyons even in periods of high sea level in areas of high sediment flux (Burgess and Hovius 1998; Carvajal et al. 2009; Dixon et al. 2012).

The Blum et al. (2013) connection model, discussed above (Fig. 3), assumes that conservation of sand within the closure depth of the longshore drift system means that sand would be transported to deep water only when the river mouth to canyon head distance is less than or equal to $2 \mathrm{~km}$, whereas mud would be transported off the shelf when that distance is less than or equal to $20 \mathrm{~km}$. Using these distances, they illustrated the inherently different connection times between fluvial systems and canyon heads for low- and high-gradient river systems (wider vs. narrower shelves, respectively) under amplitudes of sea-level change that might be typical of icehouse and greenhouse conditions.

Our data support this model, as does published data from well-studied Gulf of Mexico systems (e.g., Prather et al. 2012; Sylvester et al. 2012), which formed during late Quaternary glacial-interglacial cycles. More broadly, in the current icehouse world, large low-gradient systems with broad shelves, like the Amazon, Mississippi, Brazos, and Rhone, delivered significant volumes of sand to their respective canyons only during the last-glacial period of minimum sea level, whereas very steep-gradient (i.e., narrow shelf) systems like the Var and Monterrey still deliver sand, and even gravel, during the current sea-level highstand. Transfer of mud across the shelf margin occurs over longer time periods in all systems, but virtually ceases in moderate to large low-gradient systems with broad shelves during periods of high sea level like that of the present, when shorelines reside in mid-shelf or farther landward positions.

Our data suggest that the proximity of canyon heads to either river mouths or longshore drift systems is the first-order boundary condition that controls the grain size of sediment that passes into deep water. However, there are a number of controls that result in changes in the time periods over which connection with the slope and basin floor must occur for different grain-size fractions. As suggested in the literature for decades, relative sea-level change is the most important allogenic forcing mechanism because of the corresponding forced transits of river mouths and shorelines across the shelf. In the Blum et al. (2013) model, shelf gradient was treated as a self-formed continuation of the gradient of the river system that feeds the shoreline, and therefore as a function of the size of the river system. River slope is inversely proportional to drainage area (Flint 1974), hence, in the Blum et al. (2013) model, larger systems have inherently low river and shelf gradients, and smaller systems have inherently steeper gradients. As shelf margins generally reside at common depths that correspond to periods of low sea level, low-gradient river and shelf profiles produce inherently wider shelves, whereas steep-gradient river and shelf profiles produce inherently narrow shelves (e.g., Fig. 5). It follows that physical processes that constrain the length scales of crossshelf sediment dispersal ensure that large, low-gradient vs. short, steepgradient systems have inherently different connection times, and produce inherently different stratigraphic signatures from the same cycles of relative sea-level change.

A second implication is that icehouse versus greenhouse intervals, with different amplitudes of high-frequency (Milankovitch) forcing from relative sea-level change, will have inherently different slope to basinfloor stratigraphic signatures. As noted above, if shelf gradients are linked to river gradients, then shelf widths scale to the amplitude of sealevel change. This relationship, in turn, provides for simple geometric prediction of shelf widths at times when the amplitude of high-frequency sea-level changes were different from the present icehouse conditions. For example, a moderate- to large-size, low-gradient river system that feeds a shelf that is $100 \mathrm{~km}$ wide during icehouse conditions, with $\Delta \mathrm{SL}=$ $100 \mathrm{~m}$, would have a shelf that is only about $20 \mathrm{~km}$ wide in a greenhouse world with $\Delta \mathrm{SL}=20 \mathrm{~m}$. This model is consistent with previous discussions that inferred fundamentally different stratigraphic signatures from Milankovitch-scale forcing during icehouse vs. greenhouse periods (e.g., van der Zwan 2002).

A number of other controls play critical roles either in general or in specific cases. We summarize these here as follows:

1) The orientation of littoral cells relative to the location of canyon heads. Because longshore drift directions are determined by wind directions and coastline orientation, it is possible that longshore drift can advect sediment away from canyons that have penetrated the shelf.

2) Consideration of closure depth suggests that a refinement to this model would be to include the effect of wave energy as a secondorder control on the duration of connection as this affects the distance to which sand can be transported across the shelf.

3) Once a connection is established, climate and provenance begin to exert a control on the quantity and caliber of sediment supplied to deep water (e.g., Ducassou et al. (2009), Covault and Graham (2010), and Covault et al. (2010).

Our data explain why some submarine fans have been active in the Holocene and others are inactive, but these data also have larger implications for understanding sedimentation and deep-water reservoir distribution for other periods of geologic time. A testable hypothesis is that during greenhouse times when sea level was relatively high and stable, and Milankovitch-forced high-frequency changes were minimal, longer-lived connection between fluvial to nearshore environments and deep water might have been more likely to occur. This scenario could favor the development of thick, laterally extensive sand-rich basin-floor deposits. By contrast, icehouse periods with high-amplitude Milankovitch-forced sealevel fluctuations and inherently wider shelves likely included repeated cross-shelf transits of river mouths and shorelines, and inherently shorter connection times between source and sink, especially for sand-size sediment. The resulting deep-water deposits will have a significant mud component and periods of basin-wide sediment starvation in deep water. With further research it should be possible to determine if, early in the exploration cycle, criteria such as shelf width, greenhouse versus icehouse conditions, and location of canyon heads can be used to help assign risk to 
pre-drill assessments of the volume of sand present in a deep-water fan prospect.

\section{CONCLUSIONS}

Data from modern submarine canyons and fans indicate that all modernday submarine fans are linked to canyons. Data compiled from twenty-five modern submarine canyons show that active canyons mantled by gravel and sand occur where the canyon head is less than $1 \mathrm{~km}$ from the shore, whereas canyons characterized by active sand transport have canyon heads that are always $<5 \mathrm{~km}$, and most commonly $<1 \mathrm{~km}$ from the shoreline. Canyons with active deposition of silt-and clay-size sediment have canyon heads that are $<40 \mathrm{~km}$ from the shoreline. Systems where the canyon head is $>40 \mathrm{~km}$ from the shoreline are generally inactive and characterized by deposition of thin, carbonate-rich pelagic sediments. Although distance from canyon head to shoreline exerts the primary control on the caliber and flux of sediment that is transported to deep water, especially for the sand fraction, other factors, including the strength and location of littoral cells and the presence of mud-rich subaqueous clinothems will exert a control on the quantity and caliber of sediment that is transported into deep water. Once a connection has been made, climatically driven changes in sediment flux and the volume and caliber of sediment derived from the source area will also exert a control on the volume and grain size of sediment present in deep-water deposits.

From an exploration standpoint, these data help refine existing sequence stratigraphic models that suggest that times of relatively low sea level represent the highest probability of sand deposition in deep water, especially in basins with wide shelves and in icehouse periods of highamplitude, high-frequency sea-level variation. Our data suggest that submarine canyons on the slope are necessary as a conduit for sand transport into deep water. It should be possible in frontier basins to identify these canyons (which can be over a kilometer deep) even on coarse grids of 2D seismic data. In basins characterized by narrow shelves, and/or in greenhouse periods that lack high-amplitude, high-frequency sea-level variation, it is possible for long-lived connections between submarine canyons and fans to occur, for example the Eocene Tyee Formation of Oregon (Santra et al. 2013). In these cases sediment flux to deep water may occur regardless of sea-level position, and may be driven instead by climate, hinterland tectonics, wave energy, and the configuration of the continental margin. In these cases, given a connection to a large river, it is possible to develop extremely large sand-rich fan deposits, like the Paleocene-Eocene Wilcox deep-water play of the Gulf of Mexico (Sweet and Blum 2011) that represent the deposits of continental-scale river systems like the present Mississippi (Blum and Pecha 2014), and formed during the Paleocene-Eocene Thermal Maximum, a time period of negligible ice volume and globally high temperatures (Zachos et. al. 2001). Sand-rich Wilcox strata extend more than $500 \mathrm{~km}$ from the equivalent shelf margin, and the entire Wilcox stratigraphic interval is $>2 \mathrm{~km}$ thick and covers $>100,000 \mathrm{~km}^{2}$ in area (Zarra 2007).

\section{ACKNOWLEDGMENTS}

Our colleagues, Serge Berné (IFREMER/University of Perpignan) and the late Bruno Savoye (IFREMER), shared their data and insights into Quaternary deep-water systems, and helped lay the intellectual groundwork for the research behind this paper. ExxonMobil colleagues Vitor Abreu, Kevin Bohacs, Katie Boldt-Love, David Cleveland, and Howard Feldman challenged us to improve our ideas and provided helpful reviews of earlier drafts of this paper. Ryan Tisdale drafted the figures. JSR reviewers Tor Sømme, Nicholas Christie-Blick, Ashley D. Harris, an anonymous reviewer, and JSR Associate Editor Stephen Hubbard offered many useful comments that improved the quality of our paper JSR Corresponding Editor John Southard carefully reviewed our manuscript before publication. We thank ExxonMobil Research Company for permission to publish this paper.

\section{REFERENCES}

Allen, J.R.L., 1970, Physical Processes of Sedimentation: London, Unwin, 248 p.

Allison, M.A., Demas, C.R., Ebersole, B.A., Kleiss, B.A., Little, C.D., Meselhe, E.A., Powell, N.J., Pratt, T.C., And Vosburg, B.M., 2012, A water and sediment budget for the lower Mississippi-Atchafalaya River in flood years 2008-2010: implications for sediment discharge to the oceans and coastal restoration in Louisiana: Journal of Hydrology, v. 432, p. 84-97.

Babonneau, N., Savoye, B., Cremer, M., and Klein, B., 2002, Morphology and architecture of the present canyon and channel system of the Zaire deep-sea fan: Marine and Petroleum Geology, v. 19, p. 445-467.

Babonneau, N., Savoye, B., Cremer, M., and Bez, M., 2010, Sedimentary architecture in meanders of a submarine channel: detailed study of the present Congo turbidite channel (Zaiango Project): Journal of Sedimentary Research, v. 80, p. 852-866.

BERNÉ S., AND GorInI, C., 2005, The Gulf of Lions: an overview of recent studies within the French "Margins" programme: Marine and Petroleum Geology, v. 22, p. 691-693.

Blum, M.D., AND HatTiER-Womack, J., 2009, Climatic change, sea-level change and fluvial sediment supply to deep-water depositional systems, in Kneller, B., Martinsen, O.J., and McCaffrey, B., eds., External Controls on Modern Clastic Turbidite Systems: SEPM, Special Publication 92, p. 15-39.

Blum, M., and Pecha, M., 2014, Mid-Cretaceous to Paleocene North America drainage reorganization from detrital zircons: Geology, v. 42, p. 607-610.

Blum, M.D., AND RoberTs, H.H., 2014, Is sand in the Mississippi River delta a sustainable resource?: Nature Geoscience, v. 7, p. 851-852.

BLum, M.D., AND TöRnQvist, T.E., 2000, Fluvial responses to climate and sea-level change: a review and look forward: Sedimentology, v. 47, p. 2-48.

Blum, M.D., Martin, J., Milliken, K., And Garvin, M., 2013, Paleovalley systems: insights from Quaternary analogs and experiments: Earth-Science Reviews, v. 116, p. 128-169. Bonnel, C., Dennielou, B., Droz, L., Mulder, T., and Berné, S., 2005, Architecture and depositional patterns of the Rhone Neofan and recent gravity activity in the Gulf of Lions (western Mediterranean): Marine and Petroleum Geology, v. 22, p. 827-843.

Boyd, R., Ruming, K., Goodwin, I., SAndstrom, M., and Schröder-Adams, C., 2008, Highstand transportation of coastal sand to the deep ocean: a case study from Fraser Island, southeast Australia: Geology, v. 36, p. 15-18.

Brown, L.F., Loucks, R.G., Trevino, R.H., And Hammes, U., 2004, Understanding growthfaulted, intraslope subbasins by applying sequence-stratigraphic principles: examples from the south Texas Oligocene Frio Formation: American Association of Petroleum Geologists, Bulletin, v. 88, p. 1501-1522.

BRUUN, P., 1963, Longshore currents and longshore troughs: Journal of Geophysical Research, v. 68, p. $1065-1078$.

Burgess, P.M., AND Hovius, N., 1998, Rates of delta progradation during highstands: consequences for timing of deposition in deep-marine systems: Geological Society of London, Journal, v. 155, p. 217-222.

Carlson, P.R., And Nelson, C.H., 1969, Sediments and sedimentary structures of the Astoria submarine canyon-fan system, northeast Pacific: Journal of Sedimentary Petrology, v. 39, p. 1269-1282.

Carvajal, C., Steel, R., and Petter, A., 2009, Sediment supply: the main driver of shelfmargin growth: Earth-Science Reviews, v. 96, p. 22-248.

Clift, P.D., Giosan, L., Henstock, T.J., and Tabrez, A.R., 2014, Sediment storage and reworking on the shelf and in the Canyon of the Indus River Fan System since the last glacial cycle: Basin Research, v. 26, p. 183-202.

Conway, K.W., Barrie, J.V., Picard K., and Bornhold, B.D., 2012, Submarine channel evolution: active channels in fjords, British Columbia, Canada: Geo-Marine Letters, v. 32, p. 301-312.

Cooper, C., Wood, J., and Andrieux, O., 2013, Turbidity current measurements in the Congo Canyon: Offshore Technology Conference Proceedings, OTC 23992, 12 p.

Covault, J.A., And Graham, S.A., 2010, Submarine fans at all sea-level stands: tectonomorphologic and climatic controls on terrigenous sediment delivery to the deep sea: Geology, v. 38, p. 939-942.

Covault, J.A., Normark, W.R., Romans, B.W., and Graham, S.A., 2007, Highstand fans in the California borderland: the overlooked deep-water depositional system: Geology, v. 35 , p. $783-786$

Covault, J.A., Romans, B.W., Fildani, A., McGann, M., and Graham, S.A., 2010, Rapid climatic signal propagation from source to sink in a Southern California sedimentrouting system: The Journal of Geology, v. 118, p. 247-259.

Currie, J.R., Emmel, F.J., AND Moore, D.G., 2002, The Bengal Fan: morphology, geometry, stratigraphy, history and processes: Marine and Petroleum Geology, v. 19, p. 1191-1223. DALY, R.A., 1936, Origin of submarine canyons: American Journal of Science, v. 31, p. 401-420.

Damuth, J.E., AND Kumar, N., 1975, Amazon Cone: morphology, sediments, and growth pattern: Geological Society of America, Bulletin, v. 69, p. 460-479.

Dixon, J.F., Steel, R.J., and Olariu, C., 2012, Shelf-edge delta regime as a predictor of deep-water deposition: Journal of Sedimentary Research, v. 82, p. 681-687.

Droz, L., and Bellaiche, G., 1985, Rhone deep-sea fan: morphostructure and growth patterns: American Association of Petroleum Geologists, Bulletin, v. 69, p. 460-479.

Ducassou, E., Migeon, S., Mulder, T., Murat, A., Capodondi, L., Bernasconi, S.M., and Mascle, J., 2009, Evolution of the Nile deep-sea turbidite system during the Late 
Quaternary: influence of climate change on fan sedimentation: Sedimentology, v. 56, p. 2061-2090.

FLINT, J.J., 1974, Stream gradient as a function of order, magnitude, and discharge: Water Resources Research, v. 10, p. 969-973.

Gameri, F., and Marani, M., 2008, Controls on Holocene deep-water sedimentation in the northern Gioia Basin: Tyrrhenian Sea: Sedimentology, v. 55, p. 1889-1903.

Gervais, A., Mulder, T., Savoye, B., And Gonthier, E., 2006, Sediment distribution and evolution of sedimentary processes in a small sandy turbidite system (Golo system, Mediterranean Sea): implication for various geometries based on core framework: GeoMarine Letters, v. 26, p. 373-395.

GoodBred, S.L., 2003, Response of the Ganges dispersal system to climatic change: a source to sink perspective view since the last interstade: Sedimentary Geology, v. 162, p $83-104$

HALLERMEIER, R.J., 1981, A profile zonation for season sand beaches from wave climate: Coastal Engineering, v. 4, p. 253-277.

Harris, P.T., and Whiteway, T., 2011, Global distribution of large submarine canyons geomorphic differences between active and passive margins: Marine Geology, v. 285, p 69-86.

Heezen, B.C., Menzies, R.J., Schneider, E.D., Ewing, W.M., and Granelli, N.C.L., 1964, Congo Submarine Canyon: American Association of Petroleum Geologists, Bulletin, v. 48 , p. $1126-1149$.

Heller, P.L., AND Dickinson, W.R., 1985, Submarine ramp facies model for delta-fed, sandrich turbidite systems: American Association of Petroleum Geologists, Bulletin, v. 69, p. 960-976.

Hill, P.S., Fox, J.M., Crockett, J.S., Curran, K.J., Friedrich, C.T., Geyer, W.R., Milligan, T.G., Ogston, A.S., Puig, P., Scully, M.E., Traykovsky, P.A., and Wheatcroft, R.A., 2007, Sediment delivery to the seabed on continental margins, in Nittrour, C.A., Austin, J.A., Field, M.E., Kravitz, J.H., Syvitski, J.P.M., and Wiberg, P.L., eds., Continental Margin Sedimentation: From Sediment Transport to Sequence Stratigraphy: International Association of Sedimentologists, Special Publication 37, p. 49-99.

Howard, J.D., AND ReIneCK, H.E., 1981, Depositional facies of high-energy beach-tooffshore sequence: comparison with low-energy sequence: American Association of Petroleum Geologists, Bulletin, v. 65, p. 807-830.

JeRVEY, M.T., 1988, Quantitative geologic modeling of siliciclastic rock sequences and their seismic expression, in Wilgus, C.K., Hastings, B.S., Posamentier, H., Van Wagoner, J., Ross, C.A., and Kendall, C.G. St.C., eds., Sea Level Changes: An Integrated Approach: SEPM, Special Publication 42, p. 125-154.

Khripounoff, A., Vangriesheim, A., Babonneau, N., Crassous, P., Dennielou, B., And SAvoYe, B., 2003, Direct observation of intense turbidity current activity in the Zaire submarine valley at $4000 \mathrm{~m}$ water depth: Marine Geology, v. 194, p. 151-158.

Liu, J.T., Kuen-JAnG, L., And Huang, J.C., 2002, The effect of a submarine canyon on the river sediment dispersal and inner shelf sediment movements in southern Taiwan: Marine Geology, v. 181, p. 357-386.

Maslin, M., Knutz, P.C., and Ramsay, T., 2006, Millennial-scale sea-level control on avulsion events on the Amazon Fan: Quaternary Science Reviews, v. 25, p. 3338-3345.

Miтchum, R.M., JR., 1985, Seismic stratigraphic expression of submarine fan, in Berg, O.R., and Woolverton, D.G., eds., Seismic Stratigraphy II: An Integrated Approach to Hydrocarbon Exploration: American Association of Petroleum Geologists, Memoir 39, p. $117-136$.

Milliman, J.D., Summerhayes, C.P., and Barretto, H.T., 1975, Quaternary sedimentation on the Amazon continental-margin-model: Geological Society of America, Bulletin, v. 86 , p. $610-614$.

Mulder, T., Savoye, B., PiPer, D.J.W., And Syvitski, J.P.M., 1998, Var submarine system: understanding Holocene sediment delivery processes and their importance to the geologic record, in Stoker, M.S., Evand, D., and Cramp, A., Geological Processes on Continental Margins: Sedimentation, Mass Wasting and Stability: Geological Society of London, Special Publication 129, p. 145-166.

NaKajima, T.A., KataYama H., and ITAKI, T., 2009, Climatic control on turbidity current deposition during the last $70 \mathrm{kyr}$ along the Toyama deep-sea channel: central Japan Sea, in Kneller, B., Martinsen, O.J., and McCaffrey, B., eds., External Controls on Modern Clastic Turbidite Systems: SEPM, Special Publication 92, p. 159-177.

Nelson, C.H., Escutia, C., Goldfinger, C., Karabanov, E., Gutierrez-Pastor, J., and De Batist, M., 2009, External controls on modern clastic turbidite systems: three case studies, in Kneller, B., Martinsen, O.J., and McCaffrey, B., eds., External Controls on Deep-Water Depositional Systems: SEPM, Special Publication 92, p. 57-76.

Nittrouer, C.A., Kuehl, S.A., Demaster, D.J., and Kowsmann, R.O., 1986, The deltaic nature of Amazon shelf sedimentation: Geological Society of America, Bulletin, v. 97, p. 444-458.

Nittrouer, C.A., Austin, J.A., Field, M.E., Kravitz, J.H., Syvitski, J.P.M., And Wiberg, P.L., 2007, Writing a Rosetta stone: insights into continental-margin sedimentary processes and strata in Nittrouer, C.A., Austin, J.A., Field, M.E., Kravitz, J.H., Syvitski, J.P.M., and Wiberg, P.L., eds., Continental Margin Sedimentation: from Sediment Transport to Sequence Stratigraphy: International Association of Sedimentologists, Special Publication 37, p. 1-48

NoRmark, W.R., 1970, Growth patterns of deep-sea fans: American Association of Petroleum Geologists, Bulletin, v. 54, p. 2170-2195.
Normark, W.R., AND CARLSON, P.R., 2003, Giant submarine canyons: Is size a clue to their importance in the rock record?, in Chan, M.A., and Archer, A.W., eds., Extreme Depositional Environments: Mega End Members in Geologic Time: Geological Society of America, Special Paper 370, p. 175-190.

Normark, W.R., Damuth, J.E., and the Leg 155 Sedimentological Party, 1997, Sedimentary Facies and Associated depositional elements of the Amazon Fan, in Flood, R.D., Piper, D.J.W., Klaus, A., and Peterson, L.C., eds., Proceedings of the Ocean Drilling Program, Scientific Results, v. 155, p. 611-655.

Normark, W.A., Meyer, A.W., Cremer, M., Droz, L., O'Connell, S., Pickering, K.T., Stelting, C.E., Stow, D.A.V., Brooks, G.R., Mazzullo, J., Roberts H., and Thayer, P., 1986, Summary of drilling results for the Mississippi Fan and considerations for application to other turbidite systems, in Bouma, A.H., Coleman, J.M., and Myers, A., Initial Reports of the Deep Sea Drilling Project, v. 86, p. 425-436.

Normark, W.R., Piper, D.J.W., Romans, B.W., Covalt, J.A., Dartnell, P., and Sliter, R.W., 2009, Submarine Canyon and fan systems of the California Continental Borderland, in Lee, H.J., and Normark, W.R., eds., Earth Science in the Urban Ocean: the Southern California Continental Borderland: Geological Society of America, Special Paper 454, p. 141-168.

Oliveira, A., Santos, A.I., Rodrigues, A., And Vitorino, J., 2007, Sedimentary particle distribution and dynamics of the Nazare canyon system and adjacent shelf (Portugal): Marine Geology, v. 246, p. 105-122.

Palanques, A., de Madron, X.D., Puig, P., Fabres, J., Guillen, J., Calafat, A., Canals, M., Heussner, S., And Bonnin, J., 2006, Suspended sediment fluxes and transport processes in the Gulf of Lion submarine canyons: the role of storms and dense water cascading: Marine Geology, v. 234, p. 43-61.

Panin, N., AND JIPA, D., 2002, Danube river sediment input and its interaction with the north-western Black Sea: Estuarine, Coastal and Shelf Science, v. 54, p. 551-562.

Paull, C.K., Ussler, W., III, Greene, H.G., Keaton, R., Mitts, P., and Barry, J., 2003, Caught in the act: the 20 December 2001 gravity flow event in Monterey Canyon: GeoMarine Letters, v. 22, p. 227-232.

Paull, C.K., Mitts, P., Ussler, W., III, Keaten, R., and Greene, H.G., 2005, Trail of sand in upper Monterey Canyon: offshore California: Geological Society of America, Bulletin, v. 117, p. 1134-1145.

Paull, C.K., Caress, D.W., Lundsten, E., Gwiazda, R., Anderson, K., McGann, M. Conrad, J., Edwards, B., And Summer, E.J., 2013, Anatomy of La Jolla Canyon system: offshore southern California: Marine Geology, v. 335, p. 16-34.

Peltier, W.R., and Fairbanks, R.G., 2006, Global glacial ice volume and Last Glacial Maximum duration from an extended Barbados sea level record: Quaternary Science Reviews, v. 25, p. 3322-3337.

Peters, S.E., And Loss, D.P., 2012, Storm and fair-weather wave base: a relevant distinction?: Geology, v. 40, p. 511-514;

Pilkey, O.H., AND CoOPER, J.A.G., 2002, Longshore transport volumes a critical view: Journal of Coastal Research, v. SI 36, p. 572-580.

PiPer, D.J.W., AND SAVoye, B., 1993, Process of late Quaternary turbidity current flow and deposition on the Var deep-sea fan, north-west Mediterranean Sea: Sedimentology, v. 50, p. $557-582$.

Popescu, I., Lericolais, G., Panin, N., Wong, H.K., And Droz, L., 2001, Late Quaternary avulsions on the Danube deep-sea fan, Black Sea: Marine Geology, v. 179, p. 25-37.

Posamentier, H.W., and Kolla, V., 2003, Seismic geomorphology and stratigraphy of depositional elements in deep-water settings: Journal of Sedimentary Research, v. 73, p. 367-388.

Posamentier, H.W., and Vail, P.R., 1988, Eustatic controls on clastic deposition II: sequence and systems tract models, in Wilgus, C.K., Hastings, B.S., Posamentier, H., Van Wagoner, J., Ross, C.A., and Kendall, C.G. St.C., eds., Sea Level Changes: An Integrated Approach: SEPM, Special Publication 42, p. 125-154.

Prather, B.E., Pirmez, C., And Winker, C.D., 2012, Stratigraphy of linked intraslope basins: Brazos-Trinity System western Gulf of Mexico, in Prather, B.E., Deptuk, M.E., Mohrig, D., Van Hoorn, B., and Wynn, R.B., eds., Application of the Principles of Seismic Geomorphology to Continental-Slope and Base-of-Slope Systems: Case Studies from Seafloor and Near-Seafloor Analogues: SEPM, Special Publication 99, p. 83-110. Pratson, L.F., And Coakley, B.J., 1996, A model for the headward erosion of submarine canyons induced by downslope-eroding sediment flows: Geological Society of America, Bulletin, v. 108, p. 225-234.

Prins, M.A., Postma, G., Cleveringa, J., Cramp, A., and Kenyon, N.H., 2000, Controls on terrigenous sediment supply to the Arabian Sea during the Quaternary: the Indus Fan: Marine Geology, v. 169, p. 327-349.

Reading, H.G., And Richards, M., 1994, Turbidite systems in deep-water basin margins classified by grain size and feeder system: American Association of Petroleum Geologists, Bulletin, v. 78, p. 792-822.

Reynolds, D.J., SteCKLER, M.S., AND COAKLey, B.J., 1991, The role of the sediment load in sequence stratigraphy: the influence of flexural isostasy and compaction: Journal of Geophysical Research, v. 96, p. 6931-6949.

Rogers, K.G., Goodbred, S.L., and Khan, S.R., 2015, Shelf-to-canyon connections: transport-related morphology and mass balance at the shallow-headed, rapidly aggrading Swatch of No Ground (Bay of Bengal): Marine Geology, v. 369, p. 288-299.

Romans, B.W., Normark, W.R., McGain, M.M., Covalt, J.A., and Graham, S.A., 2009, Coarse-grained sediment delivery and distribution in the Holocene Santa Monica Basin, 
California: implications for evaluating source-to-sink flux at millennial time scales Geological Society of America, Bulletin, v. 121, p. 1394-1408.

Ryan, W.B.F., Carbotte, S.M., Coplan, J.O., O'Hara, S., Melkonian, A., Arko, R., Weissel, R.A., Ferrini, V., Goodwillie, A., Nitsche, F., Bonczkowski, J., And Zemsky, R. 2009, Global multi-resolution topography synthesis: Geochemistry, Geophysics, Geosystems, v. 10, Q03014, doi:10.1029/2008GC002332.

Santra, M., Steel, R.J., Olariu, C., and Sweet, M.L., 2013, Stages of sedimentary prism development on a convergent margin: Eocene Tyee forearc basin, Coast Range, Oregon, USA: Global Planetary Change, v. 103, p. 207-231.

Savoye, B., PiPer, D.J.W., ANd Droz, L., 1993, Plio-Pleistocene evolution of the Var deepsea fan of the French Riviera: Marine and Petroleum Geology, v. 10, p. 550-571.

ShePard, F.P., 1941, California submarine canyons, in Shepard, F.P., and Emery, K.O., eds., Submarine Topography off the California Coast: Canyons and Tectonic Interpretation: Geological Society of America, Special Paper 31, p. 51-108.

Siddall, M., Rohling, E.J., Almogi-Labin, A., Hemleben, C., Meischner, D., Schmelzer, I., AND SMEed, D.A., 2003, Sea-level fluctuations during the last glacial cycle: Nature, v 423, p. $853-858$.

Smith, D.P., Ruiz, G., Kvitek, R., And IAmPietro, P.J., 2005, Semiannual patterns of erosion and deposition in the upper Monterey Canyon from serial multibeam bathymetry: Geological Society of America, Bulletin, v. 117, p. 112-1133.

Sømme, T.O., Helland-Hansen, W., Martinsen, O.J., and Thurmond, J.B., 2009 , Relationships between morphology and sedimentological parameters in source-to-sink systems: a basis for predicting semi-quantitative characteristics in subsurface systems: Basin Research, v. 21, p. 361-387.

Stone, G.W., and Stapor, F.W., 1996, A nearshore sediment transport model for the northeastern Gulf of Mexico coast, U.S.A: Journal of Coastal Research, v. 12, p. 786792.

Stigter, H.C., Boer, W., de Jesus Mendes, P.A., Jesus, C.C., Thomsen, L., van der Bergh, G.D., AND VAN WeERING, T.C.E., 2007, Recent sediment transport and deposition in Nazare Canyon, Portuguese continental margin: Marine Geology, v. 246, p. 144-164.

Stutz, M.L., And Pilkey, O.H., 2002, Global distribution and morphology of deltaic barrier island systems: Journal of Coastal Research, Special Issue 36, p. 694-707.

SweEt, M.L., And Blum, M.D., 2011, Paleocene-Eocene Wilcox submarine canyons and thick deepwater sands of the Gulf of Mexico: very large systems in a Greenhouse World, not a Messinian-like crisis: Gulf Coast Association of Geological Societies, Transactions, v. 61, p. 443-450.

Sylvester, Z., Deptuk, M.E., Prather, B.E., Pirmez, C., and O’Byrne, C., 2012, Seismic stratigraphy of a shelf-edge delta and linked submarine channels in the northeastern Gulf of Mexico, in Prather, B.E., Deptuk, M.E., Mohrig, D., Van Hoorn, B., and Wynn, R.B., eds., Application of the Principles of Seismic Geomorphology to Continental-Slope and
Base-of-Slope Systems: Case Studies from Seafloor and Near-Seafloor Analogues: SEPM, Special Publication 99, p. 31-59.

Traykowski, P., GeYer, W.R., IrISH, J.D., AND LyNCh, J.F., 2000, The role of wave-induced density-driven fluid mud flows for cross-shelf transport on the Eel River continental shelf: Continental Shelf Research, v. 20, p. 2113-2140.

VAIL, P.R., 1987, Part 1: Seismic stratigraphy interpretation procedure, in Bally, A.W., ed., Atlas of Seismic Stratigraphy, Volume 1: American Association of Petroleum Geologists, Studies in Geology 27, p. 1-10.

Vail, P.R., Mitchum, R.M., JR., And Thompson, S., III, 1977, Seismic stratigraphy and global changes of sea level, part 3: relative changes of sea level from coastal onlap, in Peyton, C.E., ed., Seismic Stratigraphy: Applications to Hydrocarbon Exploration: American Association of Petroleum Geologists, Memoir 26, p. 63-82.

VAN DER ZwAN, C.J., 2002, The impact of Milankovitch-scale climatic forcing on sediment supply: Sedimentary Geology, v. 147, p. 271-294.

Walsh, J.P., AND NitTrouer, C.A., 2003, Contrasting styles of off-shelf sediment accumulation in New Guinea: Marine Geology, v. 196, p. 105-125.

Walsh, J.P., Alexander, C.R., Gerber, T., Orpin, A.R., And Sumners, B.W., 2007, Demise of a submarine canyon? Evidence for highstand infilling on the Waipaoa River continental margin, New Zealand: Geophysical Research Letters, v. 34, no. L20606.

WARRICK, J.A., 2014, Eel River margin source-to-sink sediment budgets: revisited: Marine Geology, v. 351, p. 25-37.

WARrick, J.A., AND Farnsworth, K.L., 2009, Dispersal of river sediment in the Southern California Bight, in Lee, H.J., and Normark, W.R., eds., Earth Science in the Urban Ocean: The Southern California Continental Borderland: Geological Society of America, Special Paper 454, p. 39-52.

Weber, M.E., Wiedicke, M.H., Kudrass, H.R., Hubscher, C., and Erlenkeuser, H., 1997, Active growth of the Bengal Fan during sea-level rise and highstand: Geology, v. 25, p. 315-318.

Weimer, P., 1989, Sequence stratigraphy of the Mississippi Fan (Plio-Pleistocene), Gulf of Mexico: GeoMarine Letters, v. 9, p. 185-272.

Zachos, J., Pagani, M., Sloan, L., Thomas, E., And Billups, K., 2001, Trends, rhythms and aberrations in the global climate 65 Ma to present: Science, v. 292, p. 686-693.

ZARRA, L., 2007, Chronostratigraphic framework for the Wilcox Formation (upper Paleocene-lower Eocene in the deep-water Gulf of Mexico: biostratigraphy, sequences and depositional systems, in Kennan L., Pindell, J., and Rosen, N.C., eds., The Paleogene of the Gulf of Mexico and Caribbean basins: Processes, Events, and Petroleum Systems: SEPM, Gulf Coast Section, 27th Annual Bob F. Perkins Research Conference, p. 81-145.

Received 6 March 2015; accepted 13 June 2016. 